\title{
The Refugees We Are: Solidarity, Asylum, and Critique in the European Constitutional Imagination
}

\author{
Paul Linden-Retek* (1) \\ University at Buffalo School of Law, Buffalo, New York \\ *Corresponding author: paul.linden-retek@yale.edu
}

(Received 26 June 2020; accepted 16 September 2020)

\begin{abstract}
This Article aims to reimagine post-national legal solidarity. It does so by bringing debates over Habermasian constitutional theory to bear on the evolving use of mutual recognition and mutual trust in the EU's Area of Freedom, Security, and Justice (AFSJ), particularly in the context of European asylum law and reforms to the Dublin Regulation. Insofar as critiques of Habermasian "constitutional patriotism" apply to the principle of mutual trust, the Article suggests why post-national solidarity requires fallibilism and dynamic responsiveness that exceed formalized rules of forbearance and respect.

On this revised view, legal solidarity guarantees a particular form of adjudication through which individual litigants in a particular case challenge the transnational structural conditions that give rise to individual harm. Because it acknowledges that violations of individual rights are always potentially or in part the result of a collective systemic failure, this conception of solidarity restores meaning to the transformative "transfer" of sovereignty that post-national law had promised. In the field of asylum law, I detail how this application of solidarity would offer a much-needed corrective to structural imbalances in the existing Dublin regime. I conclude with reflections on the principle's application in additional fields of EU law, as well.
\end{abstract}

Keywords: Solidarity; post-national law; constitutional patriotism; mutual trust; Dublin Regulation

\section{A. Constitutional Imagination, Solidarity, and the Matter of Self-Critique}

When Czech President Václav Havel returned in 2000 to speak before the European Parliament, he directed criticism to the adequacy of the European Union's cosmopolitan and universalist aspirations. Havel's concern was the immanent enlargement of the EU toward the East, which would soon include his own Czech Republic. The question of enlargement for Havel meant a confrontation with new horizons for the EU's own self-understanding. ${ }^{1}$

He knew the incorporation of post-socialist states and their citizens, were they to be true equals in partnership, would require the European Union to confront much more forthrightly than it had before questions of identity, shared responsibility, and social justice across areas of very uneven economic development and distinct historical experience. In light of the 1999 NATO intervention in Kosovo and Serbia and the preceding turbulent acceptance in the mid-1990s of refugees from

Paul Linden-Retek is Lecturer in Law \& Society at the University at Buffalo School of Law and Research Fellow at the Baldy Center for Law \& Social Policy, The State University of New York (SUNY). He holds a Ph.D. in Political Science (Yale University), a J.D. (Yale Law School), and a Bachelor of Arts in Social Studies (Harvard University).

${ }^{1}$ This point is well articulated in Seyla Benhabib \& Stefan Eich, Restructuring Democracy and the Idea of Europe, in THE Cambridge History of Modern European Thought (W. Breckman \& P. Gordon eds., 2019).

(C) The Author(s), 2021. Published by Cambridge University Press on behalf of the German Law Journal. This is an Open Access article, distributed under the terms of the Creative Commons Attribution licence (http://creativecommons.org/licenses/by/4.0/), which permits unrestricted re-use, distribution, and reproduction in any medium, provided the original work is properly cited. 
the former Yugoslavia, such questions would also prompt the European Union to consider its own commitments to the world-and to the world's inherent and shifting plurality.

Recalling his previous address to the European Parliament in 1994, Havel drew parallels between the need to confront such questions and the dwindling legitimacy of Europe's functionalist mode of technical and economic integration. If questions of value and identity became subjects for European integration only belatedly, it was because such matters seemed self-evidently clear after the horrors of the Second World War, Havel argued. And similarly, the meaning of "Europeanism" had become a question only belatedly because it, too, had deceptively come "so naturally." ${ }^{2}$ But in the same way the EU's functionalist constitution privileging a liberalized common market has in time proven inadequate, ${ }^{3}$ so too have the seemingly "natural" perceptions of European self-understanding. "[I]f Europe has thought so little about its own identity in the past," Havel said, "that is no doubt because it considered itself, wrongly, to be the entire world; or at least it considered itself to be better than the rest of the world, because it did not feel the need to define itself in relation to others."

For Havel, there was a connection between finding an alternative to European functionalist law and recovering the meaning of one's solidarity with others. The coming Eastern enlargement for Havel would require the European Union to think more carefully about how a deeper and new array of divergent histories, socioeconomic structures, and political expectations among states could be integrated in an overarching solidaristic commitment to continue living together. It would press the issue of which kinds of difference and diversity would be tolerated, which values and preferences would be accepted, and which would not.

But Havel's concern was not merely to secure accommodation of Eastern and Central Europe in the already established legal space of the European Union. His vision of solidarity was more subtle and reflexive; it entailed a mutual encounter. In pointing to the naturalizing insularity of "Europeanism," Havel connected the external dimensions of recognition among states with a process of internal critique within them. Solidarity here entails reaching out but also reaching in-reflection on one's external obligations but also reflection on one's internal presumptions of identity, authority, and self-understanding. To invoke Europe's solidarity-following Havel's line of thought-is inevitably an act of self-critical imagination. It is to call to mind other possibilities, other kinds of relationships with one's own society and with others, and new responsibilities to the world.

One is reminded here of Giorgio Agamben's submission that only when "the citizen has been able to recognize the refugee that he or she is-only in such a world is the political survival of humankind today thinkable." 5 Agamben carries the figure of the refugee from its context in the laws of asylum to the heart of civic consciousness underpinning post-national law. In thinking through what is owed to the foreigner and the refugee, the citizen "clears the way" for new understandings of nationality itself — and its potential for realizing solidarity anew. ${ }^{6}$

In this Article, I take inspiration from this idea-this connection we see, with Havel and Agamben, between post-national solidarity in Europe and critical imagination-and try to understand its consequences for European law and constitutional theory. Specifically, I aim to put forward a revised conception, in light of this philosophy, of solidarity as a legal principle.

Theorists of European integration of course have long conceived the post-national civic relationship to be a product of law. Solidarity beyond the borders of the nation-state was to be a practical realization of the "integration through law" project, a set of sentiments and commitments mediated by the form and force of legal agreement. Yet, in times of instability and crisis, European law has hardly secured such solidarity_-for the social and economic freedoms of Greek

\footnotetext{
${ }^{2}$ Václav Havel, Address before the European Parliament, Strasbourg, (Feb. 16, 2000).

${ }^{3}$ See generally Turkuler Isiksel, Europe's Functional Constitution: A Theory of Constitutionalism Beyond the STATE (2016).

${ }^{4}$ Havel, supra note 2 .

${ }^{5}$ Giorgio Agamben, Means without End: Notes on Politics 25 (V. Binetti \& C. Casarino trans., 2000).

${ }^{6} I d$. at 23 .
} 
citizens, for example, or the rights of refugees to safely seek asylum. These cases have seen, to the contrary, a punitive use of legalism to deny solidaristic politics. They are therefore paradoxical, poignant failures in need of explanation. Indeed, they suggest a serious limitation in the way European constitutional thought has imagined the constitutive links between solidarity and post-national law.

Solidarity as a legal principle has been given erratic and skeptical treatment in European jurisprudence, deemed an elusive and limited tool to pursue fair and mutual obligations among EU Member States and citizens. Indeed, scholars have observed that the concept has prompted complex responses from national politics, some concerned specifically that post-national solidarity carries considerable ideological residue of neoliberal market pressures as the valence of its solidaristic commitment. After more ambitious use in earlier case law, the European Court of Justice, for its part, has applied the principle reluctantly-and vaguely where it has done so. The ECJ's hesitance to give solidarity clear legal effect reflects the degree to which its meaning remains both politically contested and philosophically inscrutable.

But this unsettled question of solidarity as a legal principle calls into question a key ambition of contemporary constitutional law: namely its role in social integration of a complex, pluralistic, and post-metaphysical polity. Because legality remains essential to the work of European integration in times of great diversity and instability, the relationship of solidarity to law in a post-national legal order merits greater scrutiny, perhaps revaluation.

This Article develops theoretical steps toward such a revaluation. On my account, post-national solidarity requires a certain kind of legal recognition that reflects (a) terms of mutual dependency and mutual responsibility, and, just as importantly, (b) a dynamic responsiveness to how such responsibility evolves outside of one's control and thus requires critical re-interpretation over time. This latter responsiveness requires accepting a higher order of self-critique and challenging the subtle ways one's desire for mastery continues to set the terms for recognizing others. And while this second dimension is therefore essential to changing the manner in which sovereign political authority is exercised, it has also been the aspect of solidarity neglected by theorists of post-national and European constitutionalism. This is a salient reason, I argue, why existing understandings of solidarity have proven insufficiently attuned to the claims of excluded or marginalized others - whether fellow Member States or individuals - and have instead often reproduced unjustified hierarchies and inequalities.

If, as Havel intimates, solidarity requires this responsiveness as a displacement of sovereign control, solidarity expresses not merely an enlarged conception of the common good. It also names a constitutional structure and a political culture in which citizens remain self-critical about the contours of that conception: its scope of enforcement, its normative meaning, and its grounds of legitimacy. Solidarity institutionalizes mutual critique as much as it does mutual support. This dynamic, reciprocal relation resists the passive ascription of nationality as a presumption that naturalizes membership and belonging for some over others. It asks citizens to understand the ways they are always in the process of seeking exodus and refuge in their own political lives-again, in Agamben's phrase, to understand "the refugees they are." Particular interpretations or applications of solidaristic commitments in law-whether in the internal market, economic governance, or migration policy - are predicated upon this broader imagined sense of how solidarity works.

This Article aims to illuminate this symbolic structure of solidarity and its concrete expression in EU law through a comparative analysis of contemporary constitutional theory and the evolving use of mutual recognition and mutual trust in the Area of Freedom, Security, and Justice (AFSJ), particularly in the context of European asylum law and ongoing reforms to the Dublin Regulation. The limitations of solidarity in this area of law specifically-where the citizen encounters the refugee and also encounters the idea of the citizen-as-refugee-suggest critical limitations to the European Union's project of post-national constitutionalism, more generally. They pose profound questions, I believe, for how Europeans might better imagine solidarity to function through law and legal institutions_-and as a principle to guide public life. Such reforms become all the more 
trenchant as the Treaty of Lisbon has given solidarity positive legal expression in Article 80 of the Treaty on the Functioning of the European Union (TFEU).

The Article is structured as follows: Section B elaborates the tensions of solidarity as a legal principle presently found in European law. To better conceive the relationship of solidarity to law, Section $C$ turns to the most prominent expression of civic solidarity in contemporary European constitutional theory - the concept of "constitutional patriotism" articulated most comprehensively in Jürgen Habermas's discourse theory of law. In elaborating the terms of constitutional patriotism, I trace how it finds clearest expression in the legal architecture of mutual recognition and the principle of mutual trust in EU asylum law.

Section $\mathrm{D}$ then develops a critique of constitutional patriotism's limitations and illustrates how it also applies to the principle of mutual trust-with analyses of how EU law fails at once to protect individual rights and the equality of Member States. These limitations frame ongoing litigation over whether the principle of mutual trust must underwrite the forced transfers of asylum-seekers under the Dublin Regulation-notwithstanding the practice's incompatibility with emerging standards of rights protection as interpreted by the European Court of Human Rights.

In light of this critique, Section $\mathrm{E}$ argues that solidarity as a legal principle is more compellingly conceived as a legal claim for mutual critique and responsiveness. Because responsiveness requires attention to the manifestations of particular harms, solidarity entails a form of judgment that centers the individual litigant and the particular case in an assessment of the adequacy of broader structural relations. This process is itself unpredictable and creative, driven by the exigencies of the case at hand. In the field of asylum law, I detail how the application of solidarity would offer a much-needed corrective to the structural imbalances of the Dublin Regulation. I conclude with reflections on the principle's application in additional fields of EU law, as well.

\section{B. Solidarity as an Elusive Concept in EU Law}

Since Robert Schuman's declaration that Europe shall be built through concrete achievements of "de facto solidarity," solidarity has been a central, if tenuous, feature in the European Union's legal discourse. While the original European treaties left the legal meaning of Schuman's words inchoate, the present constitutional texts establish solidarity among the EU's "classical principle[s]" of law, which play a "normative founding function for the whole of the Union's legal order." Article 2 of the Treaty on European Union (TEU) lists solidarity as a value "common to Member States," and Article 3 TEU specifies that the EU shall promote solidarity between generations, among Member States, and among peoples. ${ }^{9}$ Solidarity also reflects the principle of sincere cooperation found in Article 4(3) TEU which requires a collective commitment by both the European Union and Member States to fulfill their obligations "in full mutual respect" and correspondingly to prevent or restrain from conduct that might "jeopardize the attainment of the Union's objectives." 10 These provisions are intended to strengthen EU states' commitment outlined in the TEU's Preamble "to deepen the solidarity between their peoples while respecting their history, their culture and their traditions." 11 As Advocate General Bot has recently argued, solidarity reflects "the quintessence of what is both the raison d'etre and the objective of the

\footnotetext{
${ }^{7}$ Robert Schuman, Minister Foreign \& Eur. Aff., Declaration of 9 May 1950 ("L'Europe ne se fait pas d'un coup ni dans une construction d'ensemble, mais par des réalisations concrètes créant d'abord une solidarité de fait.").

${ }^{8}$ Armin von Bogdandy, Founding Principles, in Principles of European Constitutional Law 53, 21 (A. von Bogdandy \& J. Best eds., 2010). See also EJC, Joined Cases C-402/05 P and C-415/05 P Kadi, para. 304 ECLI:EU:C:2008:11, Judgement of 3 Sept. 2008 (understanding the EU Treaties "in no circumstances [to] permit any challenge to the principles that form part of the very foundations of the Community legal order.").

${ }^{9}$ Treaty of Lisbon Amending the Treaty on European Union and the Treaty Establishing the European Community, Dec. 13, 2007, 2007 O.J. (C 306) 1.

${ }^{10}$ Treaty on European Union, 7 February 1992, 1992 O.J. (C191) 1, art. 4(3).

${ }^{11} I d$.
} 
European project" and in this sense forms an overarching "founding and existential value of the Union."12

Solidarity here aims to modulate and transform the national interest as refracted through responsibilities toward a European common good. ${ }^{13}$ Von Bogdandy emphasizes that this evolving design of the treaty's solidarity provisions affirms the EU as more than an intergovernmental agreement among States yet still distinct from a federal polity. ${ }^{14}$ Nevertheless, the present and ongoing ways European law has asserted responsibilities of solidarity are difficult; their interactions are complex and often counterproductive in their attempt to redefine insular prerogatives of national sovereignty. Indeed, as it exerts specific pressures on the nature of national obligations, the meaning of solidarity remains controversial.

Beyond its status as a broad structuring principle of EU constitutional law, theorists have attempted to clarify how dimensions of post-national solidarity result from the normative and practical requirements of European freedoms of movement and the EU's multi-level system of governance. Floris DeWitte, for example, has described the market, communitarian, and aspirational solidarities that oblige EU states to open certain kinds of social resources-such as unemployment insurance, welfare benefits, healthcare, primary and secondary education, et cetera-at various levels of governance to non-nationals depending on the nature and degree of their associational ties in the host state polity. ${ }^{15}$ The intent is as much to establish non-discriminatory criteria for access as to preserve the general stability and coherence of national redistributive systems. Similarly, Rainer Bauböck has disaggregated T.H. Marshall's original trichotomy of citizenship ${ }^{16}$ by space, time, and structure befitting the correspondingly disaggregated sovereignties above and below the nation in today's complex post-national regimes. ${ }^{17}$ Both theories rearrange solidaristic obligations by recasting relations of social belonging in terms of duration in time and proximity in space.

While there is much to recommend about these visions of differentiated commitments, there remain salient gaps in this manner of resolving the issue of post-national solidarity. Neither Bauböck nor DeWitte sufficiently addresses how these disparate levels of solidarity are meant to relate to one another-not whether they are compatible at any point in time, but more importantly how they mutually affect one another over the course of time. In this regard, Alexander Somek is less sanguine. He has warned that such a model acts upon national solidarity, "altering its meaning." ${ }^{18}$ Drawing on Tocqueville, Somek laments this distortion as an overriding ideological pressure of "individualism": "the political worldview of neoliberalism" that reduces questions of public provision to financial viability, efficiency, and flexibility. ${ }^{19}$ "Intriguingly," Somek writes,

\footnotetext{
${ }^{12}$ Opinion of Advocate General Bot, ECJ, Joined Cases C-643/15 and C-647/15, Slovak Republic and Hungary v. Council, ECLI:EU:C2017:618, paras. 17-18.

${ }^{13}$ See, e.g., Case 39/72 Commission v. Italy, ECLI EU:C:1973;13 (Sept. 6, 2017), paras. 20-25, https://curia.europa.eu/juris/ liste.jsf?num=C-39/72; Case 128/78 Commission v. United Kingdom, ECLI EU:C:1979:32 (Feb. 7, 1979) para. 12, https:// curia.europa.eu/juris/liste.jsf?language $=$ en, $T, F \&$ num $=128 / 78$.

${ }^{14}$ Bogdandy, supra note 8 , at 53.

${ }^{15}$ Floris DeWitte, Justice in the EU: The Emergence of Transnational Solidarity, 9 EUR. J. L. STUD. 241 (2015).

${ }^{16}$ See T.H. Marshall, Class, Citizenship, and Social Development: Essays, 71-134 (1964).

${ }^{17}$ Rainer Bauböck, Citizenship and Collective Identities as Political Sources of Solidarity in the European Union, in THE Strains of Commitment: The Political Sources of Solidarity in Diverse Societies 80 (K. Banting \& W. Kylicka eds., 2017).

${ }^{18}$ Alexander Somek, Solidarity Decomposed: Being and Time in European Citizenship, 32 EuR. L. Rev. 787, 814 (2007).

${ }^{19} \mathrm{Id}$. at 814 . Here, Somek points, for example, to the underlying individualistic, competitive ideological shift of Commission v. Austria, where the European Court of Justice "effectively forced upon Austria a 'merit based' system of admission" to its public universities, with the regressive effect being that lower-income and less mobile Austrian taxpayers now would support middle-class, non-national youth likely to leave Austria once they completed their studies. "It is difficult to make out," Somek concludes, "how in these instances catering to the desires of the mobile class helps to create an ever closer union among the peoples or Europe." Id. at 818. Similar arguments can be made with respect to other categories of socio-economic rights, most prominently health care. See also, Case C-120/95, Nicolas Decker v. Caisse de maladie des employes prives, 1988 ECR I-1831; Christopher Newdick, Citizenship, Free Movement and Health Care: Cementing Individual Rights by Corroding Social Solidarity 43 Common MKT. L. Rev. 1645, 1663 (2006).
} 
"with the prevalence of individualism, national solidarity begins to appear both ugly and unkind," no longer a marker of social commitment or public right but of potential private gain. ${ }^{20}$

Somek's caution about the underlying neoliberal individualism in these arrangements of postnational solidarity seems all too astute in light of prominent failures of solidaristic action in Europe's contemporary crises. Two examples — each, in a sense, with its epicenter in Greeceare symptomatic. Consider how the proposal by the European Commission to reform the Dublin Regulation concerning responsibilities to lawfully examine asylum claims serves, in fact, merely to retrench the system's fundamental inequality toward peripheral EU states and to penalize asylum seekers in the interests of preventing their secondary movement. ${ }^{21}$ And similarly consider - at the height of the Eurozone crisis - the legalistic invocation by Member States of the "no bailout" clause in Article 125 TFEU as grounds to refuse the needed restructuring of Greek sovereign debt and thus to affirm the morality play of "lazy Greeks" failing to repay hard-working "northerners." 22 This forgets, of course, not only the structural factors driving the crisis, including the risk eagerly assumed by the northern banking sector financing southern loans, ${ }^{23}$ but much more importantly the significant leniency historically afforded under EMU budgetary rules to larger, more powerful states at Europe's core. ${ }^{24}$

These shortcomings suggest the degree to which the use of solidarity in EU law remains in essential ways subordinate to existing, predominant interests - whether national or supranational and systemic - and its rarity and weakness in defending a transformative conception of the common good. ${ }^{25}$ Indeed, the Court of Justice of the EU, after earlier case law that pressed the boundaries of national solidarity's scope in precisely the ways Somek found questionable, has been chronically unwilling to develop a general understanding of solidarity as a discrete ground for European obligations.

Following national backlash against the Court's overly ambitious expansion of transnational social solidarity rights in the field of European citizenship law, the CJEU settled on a moderate position that accepted significant national restrictions to the provision of social assistance to those EU citizens who were economically inactive. ${ }^{26}$ Furthermore, in a number of recent cases concerning responses to the Eurozone crisis, the Court has declined to interpret the meaning or scope of solidarity as a legal principle. In Pringle, for example, the Court neglected to consider solidarity as a rationale to justify its narrow reading of the no-bailout clause-as Advocate General Kokott had urged - and instead upheld the legality of the European Stability Mechanism on the basis of its

\footnotetext{
${ }^{20}$ Somek, supra 18 , at 816

${ }^{21}$ See European Commission, Proposal for a Regulation of the European Parliament and of the Council: Establishing the Criteria and Mechanisms for Determining the Member State Responsible for Examining an Application for International Protection Lodged in one of the Member States by a Third-Country National or a Stateless Person (recast), 2016/0133 (COD) 2016. See generally Eleni Karageorgiou, The Law and Practice of Solidarity in the Common European Asylum System: Article 80 TFEU and its Added Value, 14 Eur. Pol'y Analysis 9 (2016).

${ }^{22}$ See, e.g., Paul De Grauwe, The Eurozone as a Morality Play, 5 InTEReConomics 230 (2015).

${ }^{23}$ See Wolfgang Streeck, Markets and Peoples: Democratic Capitalism and European Integration, 73 NEW LEFT REV. 63 (2012).

${ }^{24}$ See Wolfgant Streeck, Buying Time: The Delayed Crisis of Democratic Capitalism 106 (P. Camiller trans., 2014).

${ }^{25}$ See Esin Küçük, Solidarity in EU Law: An Elusive Political Statement or a Legal Principle with Substance?, 23 MAASTRICHT J. OF EUR. AND COMPAR. L. 965, 968 (2016) (arguing that "it is generally possible to speak of strict solidarity obligations only when they are driven by self-interest."). See also Andrea Sangiovanni, Solidarity in the European Union: Problems and Prospects, in Philosophical Foundations of EU LaW (J. Dickson \& P. Eleftheriadis eds., 2012).

${ }^{26}$ See ECJ, Case C-184/99, Grzelczyk, ECLI:EU:C:2001:458, para. 44 (Sept. 20, 2001), https://curia.europa.eu/juris/ document/document.jsf?docid=46599\&doclang=en; ECJ, Case C-209/03, Bidar, ECLI:EU:C:2005:169, paras. 56-57 (Mar. 15, 2005), https://curia.europa.eu/juris/liste.jsf?num=C-209/03; ECJ, Case C-158/07, Förster, ECLI:EU:C:2008:630, para. 52 (Nov. 18, 2008), https://curia.europa.eu/juris/liste.jsf?num=C-158/07; ECJ, Case C-138/02, Collins, ECLI:EU: C:2004:172, para. 67 (Mar. 23, 2004), https://curia.europa.eu/juris/liste.jsf?num=C-138/02. See generally Catherine Barnard, EU Citizenship and the Principle of Solidarity, in Social Welfare AND EU LAW 161-65 (E. Spaventa \& M. Dougan eds., 2005). See also Daniel Thym, The Elusive Limits of Solidarity: Residence Rights of and Social Benefits for Economically Inactive Union Citizens, 52 COMMON MKT. L. REv. 17 (2015).
} 
role in promoting sound budgetary policy among Member States. ${ }^{27}$ Similarly, the Court preferred a highly technical line of reasoning to assess compatibility of the ECB's Outright Monetary Transactions (OMT) Programme with Article 123 TFEU without invoking solidarity as a guiding principle. ${ }^{28}$ And in the field of asylum law, even since the codification of solidarity in Article 80 TFEU in the Treaty of Lisbon, the Court has chosen to avoid relying on the principle in disposing of cases concerning the equity of the Dublin Regulation. In Halaf, for example, the Court sidestepped the explicit question whether the Dublin II Regulation's "sovereignty clause" in Article 3(2) should be interpreted in light of Article 80 TFEU and resolved the case without mention of solidarity. ${ }^{29}$ Even where the Court has accepted that the Dublin Regulation must be read "in the light of" Article 80 TFEU - as it stated in the recent case affirming the binding nature of the emergency relocation scheme unveiled in 2015-its legal reasoning has left the content and scope of solidarity as a principle undefined. ${ }^{30}$ And in NS and ME, a case I will discuss in greater detail below, the Court accepted limits on the mandatory transfers of asylum-seekers under the Dublin Regulation while referencing solidarity merely in passing. ${ }^{31}$

Some of the troubles here arise, no doubt, from difficult conceptual tensions among Enlightenment and counter-Enlightenment views on the relevant terms and bounds of solidarity. ${ }^{32}$ But salient to the question of legal solidarity is another dimension of these crises: The disciplinary, often punitive use of legality itself. These responses disappoint, in part, because they employ the law foremost as a system of social management, absent positive reflection on the common good and judgments about what it might demand. Legal intervention is here conceived as reactive and constraining: a means to compensate for systemic deficiency, but without accompanying normative resources to critically examine the background presumptions on which present sovereign interests rest. As with Somek's individualism, European law's underlying metric of judgment for solidarity remains tied not to a polity's normative commitments and sensitivity to the needs around them, but to an individual's capacity to choose and to the legal system's capacity to efficiently manage that choice. This signals an ideological elision of historical, structural perspectives, ${ }^{33}$ and an overbearing tendency to consider law from the mindset of what Judith Shklar famously critiqued as "legalism": the "ethical attitude that holds moral conduct to be a matter of rule following, and moral relationships to consist of duties and rights determined by rules." ${ }^{34}$ In this way, European law remains caught in the functionalist teleology of systems integration, even as its inadequacy to the deeper demands of solidarity is laid bare.

Somek's critique does not itself offer a response to this problem. Nevertheless, it does encourage a more dynamic and diachronic attentiveness to how public perception of solidarity may be altered-and degraded - by certain attempts to realize post-national legal principles. He draws attention to how such realizations might in fact threaten to unravel the very notion of law as

\footnotetext{
${ }^{27}$ ECJ, Case C-370/12, Thomas Pringle v. Government of Ireland and Others ECLI:EU:C:2012:756, paras. 142-44 (Nov. 27, 2012), https://curia.europa.eu/juris/liste.jsf?num=C-370/12.

${ }^{28}$ ECJ, Case C-62/14, Gauweiler et al v. Duetscher Bundestag, ECLI:EU:C:2015:400 (June 16, 2015), https://curia.europa.eu/ juris/liste.jsf?num $=\mathrm{C}-62 / 14$.

${ }^{29}$ ECJ, Case C-528/11 Zuheyr Frayeh Halaf, ECLI:EU:C:2013:342, para. 25 (May 30, 2013), https://curia.europa.eu/juris/ liste.jsf?num $=\mathrm{C}-528 / 11$ \&language $=\mathrm{EN}$.

${ }^{30}$ See ECJ, Joined Cases C-643/15 and C-647/15 Slovak Republic and Hungary v. Council, ECLI:EU:C:2017:631, para. 253, Judgement of 6 September 2017.

${ }^{31}$ ECJ, Joined Cases C-411/10 and C-493/10 N.S. v. Sec. of State for the Home Department, ECLI:EU:C:2011:865, paras. 87, Judgement of December 2011.

${ }^{32}$ See generally Hauke Brunkhorst, The Transformation of Solidarity and the Enduring Impact on Monotheism: Five Remarks, 35 PHIL. \& Soc. CRITICISM 93, 95 (2009).

${ }^{33}$ See, e.g., Peter Verovsek, The Immanent Potential of Economic and Monetary Integration: A Critical Reading of the Eurozone Crisis, 15 Perspectives on POL. 401 (2017) ("The political determination to keep the euro-summed up in Angela Merkel's statement that 'If the euro fails, Europe fails'-has not been matched by a readiness to accept the structural imperatives of a functioning currency area.").

${ }^{34}$ Judith ShKlar, Legalism: An Essay on Law, Morals, and Politics 1 (1964).
} 
a source, not just of coordinated action, but of normative social integration. Somek's work is therefore a call to consider more carefully how post-national law might yet avoid this compromising entanglement with neoliberal individualism and a too shallow conception of systems-thinking. If, as Hauke Brunkhorst writes, "[s]olidarity dialectically combines opposites, contradictions, and differences" and therefore might serve as a "bridge between the different modes of social and systemic integration of society," 35 this dialectic remains an unfinished project in European Union law.

It poses again the question, tabled by Havel and Agamben above, of how we might differently conceive solidarity's place as a meaningful structuring principle of constitutional law, which would accordingly guide public interpretations of state competencies, shared obligations, determinations of jurisdiction and standing, and the scope of legal rights. How might solidarity intertwine social integration with social transformation anew in order to "modulate" the nature of state action and the kinds of considerations it reflects? If Article 2 TEU does indeed constitute a new "constitutional paradigm" with solidarity as a central principle to "transform existing legal relationships" and to "shap[e] and direct[] other core values and legal institutions," ${ }^{\text {"3 }}$ what are its features and how might it do so?

The enduringly elusive nature of solidarity-even in times of crisis-reflects a need to scrutinize and perhaps revaluate the imagined theoretical grounds of legal solidarity at once in European Union law and in European constitutional theory. Therefore, I aim to use theory to make sense of legal developments and, in turn, to use legal developments to make sense of theoretical claims - and hopefully to offer new ways to think about each. I turn my analysis to mutual trust, in particular, because it perhaps reflects most directly the structural ambition to see legal ties as the basis for solidarity, and because it, too, reflects the lasting, path-dependent legacies of European market integration.

Mutual trust transposes concepts and symbolic understandings from the EU's internal marketoriented policies to its ambition to create a space of other kinds of freedom and security, as well, and-perhaps most of all- to its relations with those who come to claim protection at its borders. Whether this transposition is successful and what it reveals about the ongoing struggles for solidarity through law are the subjects of the remaining sections.

\section{Mutual Trust Through the Lens of Constitutional Patriotism: Solidarity and its Preconditions}

As Brunkhorst has elaborated in his treatment of the idea, civic solidarity demands (a) a fully politicized conception of the people again "in purely legal terms as the totality of those subject to law"; 37 (b) a clear connection to the universalizing logic of human rights; ${ }^{38}$ and (c) an emphasis on the inclusion of these affected legal subjects in the process of legislation, that is, in a human right to democracy with a "strict identity of the ruling and the ruled." 39 This perspective provides an account of legal order as the medium in which solidarity is to take shape, even absent a post-national demos with thicker social ties to underwrite citizens' participation. Here, a global legal community (globale Rechtsgenossenschaft) creates a legal ethos and commitments to the effective protection of rights as conditions in which reciprocal responsibilities can be formulated and realized.

Here, Brunkhorst is indebted to a Habermasian discourse theory of law and, specifically, to Habermas's understanding of "constitutional patriotism" as a way to ground national identity in universalistic civic ties through the binding nature of the rule of law. Insofar as solidarity is

\footnotetext{
${ }^{35}$ Hauke Brunkhorst, Solidarity: From Civic Friendship to a Global Legal Community 5 (2005).

${ }^{36}$ Malcolm Ross, Solidarity-A New Constitutional Paradigm for the EU?, in Promoting SoldDARITY IN THE EUROPEAN Union 23, 36 (M. Ross \& Y. Borgmann-Prebil, eds., 2010).

${ }^{37}$ Brunkhorst, supra note 35 , at 71 .

${ }^{38} I d$. at $64-65$.

${ }^{39} I d$. at 73 .
} 
mediated by attachment to constitutional principle, it always potentially extends to new citizens, territories, and forms of recognition.

The development of constitutional patriotism spans Habermas's early writings on post-war German political identity to his contemporary efforts to ground a European political culture beyond the nation-state. ${ }^{40}$ Habermas recognizes that a legal system of rights protection "must be enduringly linked with the motivations and convictions of the citizens, for without such a motivational anchoring they could not become the driving force behind the dynamically conceived project of producing an association of [free and equal] individuals." ${ }^{1}$ Yet, Habermas has also made it clear that any theories that derive such anchoring from the "ambivalent bonding force of archaic institutions" are wedded to the now utterly discredited "metasocial guarantees of the sacred." 42 Therefore, it is constitutional patriotism - as the form of motivational affect directed towards constitutional principles themselves - that serves to supersede the particularist tendencies of pre-political ethnic-nationalist recognition, attaching instead-ultimately-to universalist rights and norms embedded in constitutional law. ${ }^{43}$ Constitutional patriotism hopes to offer a procedural basis for social cohesion and identity-formation within a post-metaphysical, pluralistic polity.

On this reading, solidarity is one of "the results or the 'product' of constitutional patriotism": in Habermas's definition, "an abstract, legally mediated solidarity between strangers." ${ }^{4}$ Solidarity is tied to the success and vitality of reasoning among citizens in the public sphere, secured by the co-original implication of private and public autonomy, by both liberal and republican participatory rights. ${ }^{45}$ Over time, this relationship of mutual and reciprocal participation assumes among citizens the structure of a shared constitutional project that exceeds the boundaries of national states and parochial political communities.

The premise is that constitutional patriotism can link together national communities without requiring or presuming an already formed and fully consolidated transnational demos, one that would make the ongoing work and negotiation of the terms of solidarity superfluous. Postnational solidarity refers to a kind of process that sits precisely at the point of this negotiation. So, too, with the EU's principle of mutual trust.

In European law, the principle of mutual trust has been a foundation for the expansion of European community from the early judgments protecting the nascent common market. In the well-known judgment in Cassis de Dijon, the European Court of Justice obliged Member States to "trust" the legal practice of fellow states with regard to the lawful production and marketing of goods such that domestic protectionist measures would be unnecessary and thereby justifiably prohibited under the European treaties. "Mutual trust" in this sense was a reciprocal commitment of Member States to the "legality and quality of each other's legal systems." ${ }^{47}$ It was the corollary to the mutual recognition of what these systems produced - a mutual solidarity, however limited to economics its essential terms were.

\footnotetext{
${ }^{40}$ See generally JAN-Werner MÜller, Constitutional PATriotism (2007).

${ }^{41}$ Jürgen Habermas, Struggles for Recognition in the Democratic Constitutional State, in MultiCULtURALISM 134 (A. Guttman ed., 1994).

${ }^{42}$ JÜrgen Habermas, Between Facts and Norms: Contributions to a Discourse Theory of Law and Democracy 27 (William Rehg trans., 1998).

${ }^{43}$ See Jürgen Habermas, Political Culture in Germany Since 1968, in The New Conservatism: Cultural CRITICISM AND the Historians' Debate (S. W. Nicholsen ed. \& trans., 1989).

${ }^{44}$ See MülLER, supra note 40, at 63; Jürgen Habermas, Why Europe Needs a Constitution, 11 NEW LEFT REV. 5, 16 (2001).

${ }^{45}$ HABERMAS, supra note 42, at 104 ("The co-originality of private and public autonomy first reveals itself when we decipher, in discourse-theoretical terms, the motif of self-legislation according to which the addressees of law are simultaneously the authors of their rights. The substance of human rights then resides in the formal conditions for the legal institutionalization of those discursive processes of opinion- and will-formation in which the sovereignty of the people assumes a binding character.").

${ }^{46}$ Case 120/78 Rewe-Zentral AG v. Bundesmonopolverwaltung für Branntwein 1979 ECR 649, para. 14.

${ }^{47}$ Evelien Brouwer, Mutual Trust and the Dublin Regulation: Protection of Fundamental Rights in the EU and the Burden of Proof, 9 Utrecht L. ReV. 135, 136 (2013).
} 
While in the first decades such principles meant primarily to protect the free movement of goods and services, the principle of mutual trust soon became vital for the cooperation of European states in matters of criminal law and, ultimately most germane for our purposes, immigration law, as well. Indeed, as the powers of the EU expanded in the "area of freedom, security, and justice" (AFSJ), mutual trust became a key mechanism for judicial cooperation reflected in the Tampere Conclusions of 1999 and later in the Stockholm Programme of 2009 concerning citizenship, security, asylum, and immigration policy. ${ }^{48}$

Mutual trust under the AFSJ, even more so than the mutual recognition of goods and services, creates a political and institutional space that approximates a post-national legal community, structured by the rule of law and the mutual affirmation of legal decisions taken elsewhere. While mutual recognition of goods and services enables cross-border flows and thus protects the rights of individuals in their private spheres, cooperation under the AFSJ entails giving mutual effect to judicial decisions. It affirms actions taken by representatives of a fellow Member State-whether decisions on claims to asylum or arrest warrants or other criminal sanctions - and thus by extension also affirms the opinions and decisions taken by that state's citizens. ${ }^{49}$ The state "not only recognizes a law as being equivalent but recognizes the judicial act in its interpretation of all relevant provisions in a given case." 50 That decisions affecting individual liberty and fundamental rights can be enforced, and not merely that the "fruits" of other legal orders can be accepted, confirms the systemic legitimacy of those decisions in light of an implicitly shared set of procedural and substantive principles. ${ }^{51}$ Citizens of the "trusting" state thus implicitly affirm the normative status of another's decisions as their own. And, conversely, the state that means to be "trusted" evokes solidarity under the expectation that its own system of law can be affirmed by another as legitimate.

Mutual trust in this sense expresses the form of commitment we find in Habermasian constitutional patriotism. One's allegiance across borders tracks the sound legal principles of fellow Member States. While different legal systems might indeed realize such principles in distinct ways, the affirmation of common, universalizing principles is enough to engender a binding and reciprocal relationship.

Like constitutional patriotism, mutual trust entails a necessary presupposition-a commitment to trust another's interpretation of principle as legitimate and enforceable without mandating that one explicitly share in that particular interpretation. Here, normativity is affirmed formally without being recreated substantively in the individual case. Trust is secured in the first instance by reference to a shared legality alone. It is thereby a principle of agreement and forbearance at once. For this reason, Kalypso Nicolaidis describes mutual trust as a "horizontal transfer of sovereignty," striking a negotiated balance that, on the one hand, "respect[s] sovereignty" by not requiring the complete harmonization of law and the centralization of authority and, on the other, "radically reconfigure[s] it" by "delinking the exercise of sovereign power from its territorial anchor." 52

Here, solidarity is a product of the relationship established by this transfer of sovereignty. But this solidarity rests on an unsteady ground. For there exists a well-known tension between the principle of a presumed mutual trust and the underlying prerequisite for that trust that comes from a certain level of explicit harmonization in the practices of Member States. ${ }^{53}$ Can there be trust, in other words, without harmonization? The shared commitment in mutual trust is

\footnotetext{
${ }^{48}$ See European Council, The Stockholm Programme: An Open and Secure Europe Serving and Protecting Citizens, 2010 O.J. (C115) 1.

${ }^{49}$ See Sandra Lavenex, Mutual Recognition and the Monopoly of Force: Limits of the Single Market Analogy, 14 J. EUR. PUB. POL'y 762, 765-66 (2007).

${ }^{50} \mathrm{Id}$. at 765.

${ }^{51}$ Id.; see also Miguel Maduro, So Close and yet so far: The Paradoxes of Mutual Recognition, 14 J. Eur. PUB. POL'Y 814, 823 (2007).

${ }^{52}$ Kalypso Nicolaidis, Trusting the Poles? Constructing Europe Through Mutual Recognition, 14 J. EuR. PUB. POL'Y 682,685 (2007).

${ }^{53}$ Id. at 686-88. See generally Kalypso Nicolaidis, Mutual Recognition Among Nations: The European Community and Trade in Services, (1993) (Ph.D. dissertation, Harvard University).
} 
predicated precisely on forgoing development of the same rules and standards across jurisdictions, thereby allowing national political and legal cultures a degree of freedom. As long as such national instantiations sufficiently reflect the same systemic principles, the broader integrity of the legal system is trusted. But the cooperative execution of another's laws nevertheless suggests the need for some minimum level of harmonization and some form of agreement reflected in the particular practices of states. Mutual trust seems to require some underlying institutional "management" of its terms that exceeds the simple conformity found in formal principles of recognition. ${ }^{54}$

The solidarity implied and created by mutual trust in this regard represents a post-national legal principle - not a formal arrangement but a dynamic of interaction, a mode of governance that requires judgment about its own scope and limits. ${ }^{55}$ If solidarity here means a commitment to protect the agency of others, can we do so for those with whom we disagree, whose agency might undermine our own and might therefore undermine the efficacy of our principles as we have conceived them? Remember that constitutional patriotism aims precisely to supersede the particularist tendencies of pre-political recognition, attaching instead to the universalist norms of constitutional law. Thus the question here is not merely how to prevent mutual trust from violating one's own principles but something deeper: On what ground are we to say such a violation is in fact illegitimate? With reference to whom, sensitive to whose concerns, and in what measure?

In posing the question this way, the principle of solidarity aims to make this tension in mutual trust productive. Assessments of mutual trust might in some instances create pressures toward explicit harmonization of laws but more broadly might, in the long-term, promote "judicial communication, mutual learning, and ultimately also approximation and trust." ${ }^{56}$ Solidarity here acquires a dynamic insofar as it depends on the adjudication and enforcement of each particular case-with the understanding that each case attests to the broader systemic legitimacy of another's rule of law and, in turn, bears in some way on the interpretation of one's own legal commitments in the home jurisdiction. Each case occasions self-introspection, self-criticism, an understanding of another's interests and how they might fit into one's own, their impact in particular cases, and whether and why these abide by one's principles. Over time, in other words, this process comes closer to forming a basis for a post-national constitutional project that might creatively expand the normative self-understandings of a common political community.

Constitutional patriotism imagines precisely this kind of "transformative conception of living together." 57 It shifts the understanding of political identity from an "unreflective" identification with particular national traditions to "dynamic and complex processes of identity-formation." 58 Constitutional patriotism is a "collective learning process," in which "citizens see their constitutional culture as always open and incomplete." ${ }^{59}$ Citizens attend, in other words, to the "refugees they are"-renegotiating the bounds and meanings of the political communities in which they seek to belong ever more fully.

Implicit, but central to the preservation of post-national solidarity under constitutional patriotism, is the idea that there is a "life of the law." Habermas, in elegant and powerful prose, embraces this spirit:

[T] he constitutional state does not represent a finished structure but a delicate and sensitive -above all fallible and revisable-enterprise, whose purpose it to realize rights anew in changing circumstances, that is, to interpret the system of rights better, to institutionalize it more appropriately, and to draw out its contents more radically. ${ }^{60}$

\footnotetext{
${ }^{54}$ Nicolaidis, supra note 52 , at $686-88$.

${ }^{55}$ See id. at 686.

${ }^{56}$ Lavenex, supra note 49 , at 776 .

${ }^{57}$ MülleR, supra note 40 , at 71.

${ }^{58} \mathrm{Id}$. at 29 (emphasis added).

${ }^{59} I d$. at 61.

${ }^{60}$ Habermas, supra note 42 , at 384.
} 
Similarly, Nicolaidis writes that the way mutual trust is managed means it must also create "critical safeguards" that make it "progressive and flexible over time." 61 This is perhaps the crucial hope of constitutional patriotism in the post-national context. If constitutional law can indeed be considered open in this fundamental sense, then competing polities might meaningfully intertwine their constitutional claims so as to support the kind of cross-border solidaristic commitments needed today.

Nevertheless, much hinges on how such processes of open-ended identity formation go forward, and more must be said about how democratic institutions and constitutional law might reflect them. And given the inadequacies of solidarity we find in Europe's contemporary crisis, there is a misgiving that such normative hopes remain in crucial respects compromised by internal contradictions buried beneath their surface. The question remains whether the specific terms of Habermas's hope for a "dynamic constitutionalism" 62 - as we see them reflected when the principle of mutual trust is put into practice-succeed in fully preserving this life of the law beyond the nation-state; and whether constitutional patriotism can indeed underwrite the kinds of political orientations, relationships, and subjectivities imagined by post-national solidarity.

\section{The Dilemmas of Solidarity: The Dublin Regulation, Formal Recognition, and the Necessity of Critique}

A key tension that structures both constitutional patriotism and mutual trust is this relation between universal norms in constitutional law and the particular ways they are interpreted, contextualized, and embedded in constitutional practice. The tension arises because it remains cleareither in the ambitions of mutual trust or in Habermas's theory-whether the real attachment capable of sustaining trust is to the principles or to particular character of the social worlds that give principles their specific meanings. The nature and post-national possibilities of solidarityprecisely as the product of this attachment - thus very much depend on the objects of attachment we have in mind. Habermas writes in an important, but ambiguous passage that "[s]olidarity ... arises out of law only indirectly, of course: by stabilizing behavioral expectations, law simultaneously secures symmetrical relationships of reciprocal recognition between abstract bearers of individual rights." ${ }^{33}$ Such stabilization involves not merely abstract rights as elements of a democratic procedural consensus but also an understanding of the meaning of these rights as citizens live and invoke them in political practice. It thereby remains somehow related, if not entirely wedded, to certain communitarian dimensions of political life.

Indeed, after early criticism that he offered resources for too thin a political bond, Habermas modulated the relationship he envisioned constitutional patriotism could establish between universal principles of communicative rationality and a particular political-cultural tradition. No longer presuming a direct attachment to universal principles simpliciter, constitutional patriotism in this new light signified a more particularized and historicized attachment - to "the political order and the principles of the [German] Basic Law." ${ }^{4}$ While Habermas never completely left behind his previous abstract formulations, his subsequent work immediately situated references to constitutional patriotism "within the historical context of a legal community" ${ }^{2}$ or simply within a "shared political culture." ${ }^{\prime \prime 6}$ The principles in positive law must be given, Habermas admits, a definite shape. He notes that "[t]he identity of a person, of a group, of a nation, or

\footnotetext{
${ }^{61}$ Nicolaidis, supra note 52, at 695.

${ }^{62}$ HABERMAS, supra note 42 , at 384.

${ }^{63} \mathrm{Id}$. at $448-89$ (emphasis added).

${ }^{64}$ Habermas, supra note 43 , at 257.

${ }^{65}$ HABERMAS, supra note 41 , at 225.

${ }^{66}$ Jürgen Habermas, The European Nation-State: On the Past and Future of Sovereignty and Citizenship, in THE INCLUSION of the Other: Studies in Political Theory 118 (C. Cronin \& P. de Greiff eds., 1998).
} 
of a region is always something concrete, something particular." 67 It cannot "consist merely in general moral orientations and characteristics, which are shared by all alike," but must instead present an "image" to oneself and others. ${ }^{68}$ To suture commitment to legal procedures, Habermas invokes a specified image of a people that is — at least for a time - unified, bounded, and fixed. ${ }^{69}$ The object of attachment, the means by which citizens feel bound and committed to the law and to one another, is this stabilization of expectations in light of a political culture of law that is historically and culturally specific.

Now, just as with the notion of mutual trust, if constitutional patriotism is to remain a source of solidarity that does not foreclose the universalizing character of law, this relationship to political culture must have rather distinct characteristics. While Habermas rules out the particularity of an ethnic or linguistic-cultural grounding for political commitment, a different sort of particularism does indeed underwrite the embrace of constitutional principles. The nature of the "shared political culture" must nevertheless be, as Habermas writes, dissociated from a "hegemonic majority culture" and "uncoupled from the level of subcultures and their prepolitical identities," such that "different cultural, ethnic, and religious forms of life [can] interact on equal terms within the same political community." 70 This is what Habermas has in mind when he reiterates that, in post-conventional societies, "republicanism must learn to stand on its own feet."71 Thus, while solidarity grounds itself in particular allegiances to different constitutions with different interpretations of the catalogue of rights, such allegiance still engenders a consciousness of the universal. In the post-national context of mutual trust, "the same legal principles would ... have to be interpreted from the perspectives of different national traditions and histories" 72 and brought into focus as part of a now transnational legal culture.

These formulations render unclear, however, what a "shared political culture" is meant to include. Specifically, what role is political culture meant to play in mediating law's rational discourse, on the one hand, and the broader cultural meanings of the lifeworld, on the other? Consider, for example, what Habermas has written specifically about the future of a European public sphere and a supranational political culture:

[To date] by and large, the national public spheres are culturally isolated from one another. They are anchored in contexts in which political issues gain relevance only against the background of national histories and national experiences. In the future, however, differentiation could occur in a European culture between a common political culture and the branching national traditions of art and literature, historiography, philosophy, and so forth. ${ }^{73}$

This construction is curious for a number of reasons. First, Habermas accepts an analytic bifurcation of politics and culture, and ostensibly of constitutional principles and their broader social imaginaries. If this is so, it is unclear how citizens are understood to live out the common political culture and perceive it as something normatively valid or socially meaningful. This risks, again, conceiving of political commitment too "thinly." Second, if we accept some kind of interrelationship between the thematization of political issues and their exploration in the broader cultural lifeworld, then the difference between the two scenarios Habermas identifies seems, in fact, to

\footnotetext{
${ }^{67}$ Jürgen Habermas, The Limits of Neo-Historicism, in AUTONOMY AND SOLIDARITY: INTERVIEWS WITH JÜRGEN HABERMAS 239 (P. Dews ed., 1996).

${ }^{68} \mathrm{Id}$.

${ }^{69}$ See also Alessandro Ferrara, Of Boats and Principles: Reflections on Habermas's "Constitutional Democracy" 29 PoL. THEORY 782 (2001) (asking what exactly Habermas understands to be the objects of political attachment under constitutional patriotism).

${ }^{70}$ Habermas, supra note 66 , at $117-18$.

${ }^{71} \mathrm{Id}$. at 117.

${ }^{72}$ Habermas, supra note 42 , at 500 .

${ }^{73} \mathrm{Id}$. at 507.
} 
be quite minimal. As long as national cultural traditions remain "branched" in this way, then it seems likely that the vocabularies and languages used in the public sphere will be "culturally isolated" in the same manner, thus reducing the second scenario to the first.

These points are highly abstract, but return for a moment to the context of mutual trust. If a "shared political culture" must mean that the terms of mutual trust reflect an underlying consensus that such terms sufficiently accommodate the particular interpretations of law that are to be mutually affirmed, how can we distinguish this from an explicitly agreed convergence of mutually applicable standards? If mutual trust in fact becomes the latter, is the relationship still one of solidarity? Or does it instead become one of rule-following in a manner that opens or "modulates" national sovereignty much less creatively or transformatively from the perspective of postnationality? Is it still the site of the kind of mutual learning post-national solidarity meant to engage as a balance of agreement and forbearance? And, conversely, if a "shared political culture" means that mutual trust does indeed remain highly formal and thin, then in what sense can mutual trust entail a solidarity that triggers critical inquiry into particular national practices-practices which can always mask power differentials that exclude without justification? Does it in this latter case simply become what Nicolaidis criticizes as mere isolated, "blind" trust?" And if "shared political culture" of mutual trust reduces to either of these two scenarios, can it still sustain the kind of emancipatory mutual learning and "dynamic constitutionalism" as imagined?

There are thus two currents circulating beneath Habermas's post-national constitutional project, and they flow against one another. Habermas certainly wishes for a kind of political culture that nests the particular historical experiences of nations in a certain manner within the universality of democratic principles. But in the examples and elaborations Habermas has offered, the idea of a "shared political culture" masks key contradictions as a substrate of post-national attachment. While Habermas is careful to avoid making a national political culture too particularembedded too firmly in cultural social groupings- he perceives the particularisms of national constitutions and their historical interpretations of rights "more benignly," as Robert Post and Reva Siegel put it. ${ }^{75}$ While the former threaten universal democratic principles and thereby require uncoupling, the latter comfortably give them concrete meaning without compromising their emancipatory orientation "one iota." 76 This seems to be the ambit, too, of constitutionalizing mutual trust in EU law. But — as we shall see with the example of the Dublin Regulation-the fear that such tension does in fact compromise the emancipatory orientation is significant, indeed.

\section{Trusting Fundamental Protections: Dublin and Mutual Recognition}

Recall that the Dublin Regulation allocates responsibility among Member States for the processing of requests to asylum according to several criteria: Alongside family unity, state issuing a legal residence or visa, and place of application, the most salient criterion in times when there is a mass movement of refugees is the first country of irregular entry. These criteria are significant, moreover, as the Dublin system permits the transfer of asylum seekers to another Member State if this state is found in fact to be responsible. Allocation criteria and the capacity to transfer support Dublin's two main purposes - as affirmed in its 2013 recast (Dublin III): (1) to ensure protection to those seeking asylum, and (2) to deter "forum shopping" and multiple applications and thereby improve the efficiency of processing and reduce costs to Member States. ${ }^{77}$ When Member States made such transfers in the past, they relied on the principle of mutual trust and presumed adequate fundamental rights protections for asylum seekers in the receiving state. Recent

\footnotetext{
${ }^{74}$ Nicolaidis, supra note 52 , at $685-86$.

${ }^{75}$ Robert Post \& Reva Siegel, Constitutional Patriotism and Constitutional Culture 12 (draft on file with author).

${ }^{76}$ Habermas, supra note 66, at 500.

${ }^{77}$ See Council Regulation No. 604/2013, Recitals 4-5, 2013 O.J. (L 180) 31.
} 
European case law has interrupted this process, ruling that mutual trust may be presumed but must be rebuttable, and thus more sensitive to the factual respect of fundamental rights in receiving jurisdictions. The ways such rulings navigate the tensions of mutual trust are instructive for our understanding of post-national solidarity.

In the context of the Dublin Regulation, the principle of mutual trust refers to the assessment that all EU Member States are safe countries for the reception of claims to asylum. This determination is expressed in the Regulation itself, referencing Member State participation in the 1951 Convention relating to the Status of Refugees and the "Common European Asylum System." It has since been further codified in successive European directives on rules of reception and asylum procedures, and is further reflected in the accession of all EU states to the European Convention on Human Rights and the non-refoulement principle interpreted in its Article 3. ${ }^{78}$

Prior to the latest round of litigation and its recent Recast, the Dublin II system imposed no obligation on Member States where applications are lodged to refrain from transfer according to Dublin criteria and assume responsibility themselves. ${ }^{79}$ Solidarity among Member States presumed the adequacy of one another's legal norms. In order to constrain duplicate applications, Member States committed to affirming one another's asylum decisions: "[R]ejected in one country, rejected everywhere." ${ }^{\prime 0}$

But this accession to shared constitutional principles has in practice belied serious deficiencies in European asylum procedures. It has obscured enduring and profound differences in the national interpretation and implementation of the above human rights agreements-with essential disparities in procedural guarantees, reception conditions, and integration capacities of Member States. And this presumption of trust based upon adequate formal standards has consistently been dispelled by critical reports of systemic failures in the asylum systems of European states at the geographic periphery of the European Union. ${ }^{81}$

Mutual trust here becomes a veneer beneath which rights protections can be hidden and tolerated-and thus certain solidarity among Member States becomes a means to deny solidarity to those who seek asylum in Europe. Yet further still, at the same time, formal solidarity of cooperation under mutual trust sanctions blindness to structural imbalances and unfairness in the allocation of responsibility among States. The "first country of irregular entry" rule, in particular, shifts responsibility rather than seeking to equitably share it.

The flawed relation of mutual trust to solidarity reveals an intrinsic instability and a gap in the Habermasian reliance on a shared legal culture as an adequate ground for post-national solidaristic relations. It again pays too little attention to how differences in implementation at the national level in fact reveal the imbalance of the presumed underlying consensus on the limits of recognition.

Habermas in his constitutional theory has responded to this gap by emphasizing the dynamic structure of agreement in legal procedures. Specifically, he appeals to the "all affected interests"

\footnotetext{
${ }^{78}$ Id.at Recitals 2-42. See also Council Directive 2003/9/EC, 2003 O.J. (L 31) 18; Council Directive 2005/85/EC, 2005 O.J. (L 326) 13; Council Directive 2004/83/EC, 2004 O.J. (L 304) 12.

${ }^{79}$ Council Regulation 343/2003, art. 20 (1), 2003 O.J. (L 50) 1.

${ }^{80}$ Nicolaidis, supra note 52, at 687.

${ }^{81}$ See, e.g., European Committee for the Prevention of Torture and Inhuman or Degrading Treatment or Punishment, Public Statement Concerning Greece, CounCIL OF Europe (Mar. 15, 2011), https://www.refworld.org/type,SPEECH, COECPT,4ee21a2a2,0.html; Thomas Hammarberg, Commissioner for Human Rights of the Council of Europe, CounCIL OF Europe (Apr. 16, 2009), https://rm.coe.int/16806db88f; EuropeAN Union AGENCY FOR FundAMENTAL RighTs, Coping With a Fundamental Rights Emergency: The Situation of Persons Crossing the Greek Land Border in an Irregular Manner (Mar. 8, 2011), https://fra.europa.eu/en/publication/2011/coping-fundamental-rights-emergency-situation-persons-crossinggreek-land-border; Human Rights Watch, Pushed Back, Pushed Around: Italy's Forced Return of Boat Migrants and Asylum Seekers, Libya's Mistreatment of Migrants and Asylum Seekers (Sept. 21, 2009), https://www.hrw.org/report/2009/09/ 21/pushed-back-pushed-around/italys-forced-return-boat-migrants-and-asylum-seekers; HuMAN RiGHTS WATCH, Greece-The EU's Dirty Hands: Frontex Involvement in Ill-Treatment of Migrant Detainees in Greece (Sept. 21, 2011), https://www.hrw. org/report/2011/09/21/eus-dirty-hands/frontex-involvement-ill-treatment-migrant-detainees-greece.
} 
democratic principle of legitimacy — the foundational dictum that a polity must "not exclude anyone who is affected by the possible coercive measures of the legal community from the community of equal citizens." ${ }^{\prime 2}$ The democratic principle thereby combines a compositional standard of inclusion with a basic procedural mechanism for guiding political participation. It is at once a counter-factual ideal for assessing the legitimacy of laws and political decisions but also a deliberative model for how public institutions ought to function. ${ }^{83}$ The question is whether this procedural view is an adequate way to conceive post-national solidaristic legality and politics.

In their response to the inadequacies of the Dublin system, European courts have relied precisely on this approach, scrutinizing mutual trust as in fact a hindrance to the effective protection of human rights. In the landmark 2011 case MSS v. Belgium and Greece, the European Court of Human Rights denied the presumption of trust as pertaining to the satisfactory treatment of asylum seekers in Greece. It thereby ruled that Belgium's transfer of an Afghan asylum seeker to Greece under the Dublin Regulation violated the European Convention's protections against inhumane and degrading treatment. ${ }^{84}$ The Court concluded that merely "the existence of domestic laws and accession to international treaties guaranteeing respect for fundamental rights in principle are not in themselves sufficient to ensure adequate protection." 85

The European Court of Justice that same year similarly affirmed that a Member State's discretion to refuse a transfer under the Dublin system in fact becomes an obligation in cases where rights of the applicant under Article 4 of the EU Charter of Fundamental Rights are in question and when "they cannot be unaware that systemic deficiencies in the asylum procedure" in the receiving state. ${ }^{86}$ Like the ECtHR, the CJEU emphasized that "the presumption underlying the Dublin mechanism, ... that asylum seekers will be treated in a way which complies with fundamental rights, must be regarded as rebuttable," specifically notwithstanding the fact that the "Common European Asylum System is based on the full and inclusive application of the Geneva Convention and the guarantee that nobody will be sent back to a place where they again risk being persecuted." ${ }^{\prime 7}$

There is of course more to these complex rulings. But important for our understanding of how responsibility is conceived is how they reject the view that mutual trust is merely a procedural matter of accession to the correct conventions with sound legal principles. In effect, the rulings require that Member States not defer to the veneer of a shared legal culture but instead scrutinize how adequately formal procedures are in fact realized by fellow States in practice. ${ }^{88}$ In MSS, the Belgian government argued that the asylum seeker had "failed to voice his fears" concerning a transfer to Greece. ${ }^{89}$ The Court rejected this argument. Rather, it emphasized that the applicant could not be "expected to bear the entire burden of proof" and that Belgium would itself need to "verify how the Greek authorities applied their legislation on asylum." 90

Dispositive was the idea that the state must share responsibility for ensuring an applicant's rights were in fact protected. Belgium could not escape its responsibilities behind a conclusive

\footnotetext{
${ }^{82}$ See Brunkhorst, supra note 35 , at 170.

${ }^{83}$ See Seyla Benhabib, Toward a Deliberative Model of Democratic Legitimacy, in DemOCRACY AND DIFFERENCE: Contesting the Boundaries of the Political (S. Benhabib ed., 1996).

${ }^{84}$ MSS v. Belgium and Greece, App. No. 30696/09, para. 342 (Jan. 21, 2011), https://hudoc.echr.coe.int/fre\#\{\%22itemid\% 22:[\%22001-103050\%22]\} ("When they apply the Dublin Regulation ... States must make sure that the intermediary country's asylum procedure afford sufficient guarantees to avoid an asylum seeker being removed, directly or indirectly, to his country of origin without any evaluation of the risks he faces from the standpoint of Article 3 of the Convention.").

${ }^{85} \mathrm{Id}$. at para. 353 .

${ }^{86}$ ECJ, Joined Cases C-411/10 and C-493/10, NS v. Secretary of State for the Home Department and ME and Others v. Refugee Applications Commissioner and Minister for Justice, Equality and Law Reform [2011] ECR I-13905, paras. $98,106$.

ECJ, Joined Cases C-411/10 and C-493/10 N.S. v. Sec. of State for the Home Department, ECLI:EU:C:2011:865 (Dec. 2011 ), paras. 98, 106.

${ }^{87} \mathrm{Id}$. at paras. 75, 104.

${ }^{88}$ See MSS v. Belgium and Greece, paras. 352, 358.

${ }^{89} \mathrm{Id}$. at para. 346.

${ }^{90} I d$. at para. 358.
} 
presumption; it was required to take responsibility for its own coercive measures-its own involvement in putting asylum seekers in harm's way-as Habermas's principle of democracy suggests. The dynamic account of solidarity here tracks this new assessment.

\section{Critical Problems and the Problem of Critique}

How are we, in the end, to read these cases? In one respect, they secured a higher level of rights protection for those seeking asylum in the procedures of the Dublin Regulation. Following the MSS ruling, most EU Member States suspended their transfers to Greece. Following the decision in NS/ME, that halt because near-universal, and the prohibition on transfers to states with "systemically deficient" asylum protections was incorporated into the Dublin Regulation's recast, Dublin III.

And, yet, in another respect, the responsibility for a state's coercive measures-and thus solidarity with the asylum seeker and fellow Member State alike-remained essentially vague. While Dublin III reflected the CJEU's language, it failed to provide further administrative or legal guidance on the meaning of "systemic deficiencies" that require a prohibition of transfer. Substantially divergent interpretations among Member States of what "systemic deficiencies" entails have meant that states have hesitated to apply the prohibition to other cases that nevertheless bear similarity to Greeceincluding inadequate processing and reception capacity in Italy or Bulgaria. ${ }^{91}$ In effect, the dilemma for solidarity of a presumed shared political commitment here resurfaces. Dublin's recast erected a new conclusive legal presumption — a new shared legal culture, in Habermas's terms - that served to forestall critique of state practice and to entrench state prerogatives anew.

Is it enough, therefore, merely to track coercion - and to include those affected by that coercion in determinations of responsibility? What if the invocation of coercion depends, in fact, on a prior understanding of what coercion means, over which those who are to be included cannot have a say? This is the criticism made by Paulina Ochoa of Habermas's understanding of dynamic constitutionalism. The "all affected interests principle," Ochoa writes, could indeed be a principle for democratic inclusion, but only when "individuals living on either side [of the boundary] could agree on an analysis and interpretation of the meaning of 'having one's interests affected by a decision." 92 In cases where such an agreement is not available prior to the decision for inclusion-as is the case with constitutionalism beyond the nation-state-reliance on the principle catches in a vicious circle. To deploy the "all affected interests principle" means already to have made a preceding judgment about the nature and scope of the decision such that those affected individuals could be included in the decision-making process; however, these same individuals could not have themselves been involved in making this prior determination. The exercise would thus become one of "constitutional paternalism," as Ochoa terms it, where the appeal for inclusion is made by a group already established in power who cannot help but treat others unequally as they were not included in defining the terms of the very principles for their inclusion. ${ }^{93}$

The problem with relying on principled inclusion is that it risks a deceptive kind of formalism. Legality-from which solidarity was meant to emerge — instead reduces to a formulaic "rule" that obscures - and thereby insulates from scrutiny - the background presumptions and relations upon which it is predicated. Law becomes a disciplinary, not a critical, force. This betrays what Patchen Markel has critiqued as an "orientation toward mastery" that in fact is left unaltered,

\footnotetext{
${ }^{91}$ See Sussan Fratzke, Not Adding Up: The Fading Promise of Europe's Dublin System, Migration Pol'y InST. Eur. 18 (2015) ("Despite increasing evidence of failings in Italy's asylum procedures, for example, most asylum authorities have been hesitant to use the logic of the CJEU's decision in N.S./M.E. to refrain from transferring claims to Italy. In Austria asylum authorities have declined to do so on the grounds that, since the Commission has not instituted infringement procedures, Italy is still fulfilling its obligations under EU law. The ECtHR also found, in 2013, that returns to Italy were permissible in specific cases.").

${ }^{92}$ Paulina Ochoa, The Time of Popular Sovereignty: Process and the Democratic State 42 (2011).

${ }^{93} I d$.
} 
unmodulated by the principle of solidarity. ${ }^{94}$ This form of legalism suppresses precisely what solidarity aims to redress: The "experience of vulnerability, to the fact that our identities are shaped in part through the unpredictable responses of other people." ${ }^{\prime 25}$ The push of legality here demands that "others recognize us as who we already really are." ${ }^{96}$ It thereby preserves the "basic aspiration behind [sovereign] agency: the aspiration to be able to act independently, without experiencing life among others as a source of vulnerability, or as a site of possible alienation or self-loss." 97

This critique is important to bear in mind. If the prohibition on transfer in these circumstances is often viewed as an important first step, it nevertheless represents a rather passive and limited understanding of what solidarity demands. Consider here how, in requiring a refusal of transfer, Dublin III also sanctioned a kind of withdrawal, where responsibility of Member States to the rights of asylum seekers was understood in isolation, despite the systemic entanglement of states and their-mutually implicated-factual capacities to respond to asylum claims. Relying on Dublin's "sovereignty clause," the basis for this "corrective" solidarity emphasizes a state's discretion to act on its own. It thus implicitly, though decisively, affirms a solipsistic ideological conceit privileging a national frame for responsibility under European refugee law.

This national frame can bear ambiguous results from the perspective of rights protection-some to heighten protection and others to reduce it. Earlier in the history of the AFSJ, for example, states in certain circumstances refused to recognize the asylum jurisdiction of fellow Member States-on the basis not of a new prospective legal agreement of humanitarian standards-but instead on account of their own criteria of refugee status and protection defined under national law. This was the approach of the UK Court of Appeals in 1999 when it denied transfer by the Home Office of asylum seekers to French and German jurisdiction on grounds that the latter's more restrictive policies failed to offer asylum, unlike the United Kingdom, on grounds of persecution by agents other than the state. ${ }^{98}$ But this same national frame also bears fruit, as it did after NS/ME, in the discretionary reluctance to apply the "systemic deficiencies" test to other states undergoing difficulties of adequately protecting refugee rights_ and thus to keep "trusting" their deficient asylum laws.

In either case, there nonetheless remains an elision of transformative post-national solidarity, as the national state exercises extensive power by continuing to "draw upon a history of relatively stabilized relations of recognition." 99 These relations enable the national state to "set the terms of exchanges of recognition, creating incentives for people to frame their claims about justice in ways that abet rather than undermine the project of state sovereignty." 100 Under the auspices of mutual trust, European states have long avoided confronting the ways individual national legal cultures and particular practices developed - and the ways these developments affected one another. With regard to the Dublin Regulation's structure and its rule on the "first country of entry," in particular, this permitted core states to ignore increased pressures on the national legal systems of states on the periphery, all the while continuing to formally abide by their rights obligations. More deeply still-as NS/ME and the Dublin III reform demonstrate-some states were thereafter permitted, under the guise of rebalancing the principle of mutual trust, to continue to "set the terms" for others - whether peripheral states or asylum seekers themselves—of equality and participation in deciding where claims to asylum are to be processed.

While formal inclusion in new discursive practices_-including new framework agreements for more equitable allocation of responsibility - may certainly produce substantial recognition of previously ignored persons or claims, it would be too hasty to conclude that this secures a robust grounding for post-national solidarity. Indeed, the opposite may very well be the case:

\footnotetext{
${ }^{94}$ See Patchen Markell, Bound by Recognition 12 (2003).

${ }^{95}$ Id. at 14 .

${ }^{96} \mathrm{Id}$.

${ }^{97} I d$. at 12 .

${ }^{98} \mathrm{R}$ v. Sec. of State for Home Dept., 1999 INLR 472 (U.K.); Lavenex, supra note 49, at 772.

${ }^{99}$ MARKELL, supra note 94 , at 30.

${ }^{100} I d$.
} 
Progress toward inclusion might instead continue to privilege - in ways remaining hidden and unaddressed-assumptions about the nature of national prerogative (an ideology that captures the underlying desires for control) in a manner that in fact inhibits solidaristic affirmation of others.

The relation between mutual trust as a dynamic balance of agreement and forbearance here becomes troublingly confused. It sheds its capacity to tender relations of mutual learning and mutual examination as a transformative "transfer" of sovereignty from which post-national solidarity emerges. If the first case suggests a concern that state power might "collude" 101 to lower rights protection, as the UK Home Office had attempted, Dublin III's indeterminacy in the second case poses the opposite problem-precisely the absence of state coordination to identify foreseeable violations of rights.

Both cases purport to resolve the tension between mutual trust and fundamental rights by in fact deepening the tension between mutual trust and the dynamic production of solidarity through law. This drives a wedge between accounts of what states owe to refugees and what they owe to one another. Recall that in NS/ME, the Court declined to develop an interpretation of solidarity as a legal principle. This oversight now comes hardly as a surprise given the Court's reliance on national discretion to resolve the case. In its formalistic understanding of how rights would now have to be protected-in the creation of a new rule, it failed to scrutinize the systemic imbalances among states that would continue to dictate that rule's interpretation and enforcement and that would themselves remain unchallenged by that rule.

Occluded in this discussion is scrutiny of what is in fact a constitutive relationship between fundamental rights protection and the fairness with which systemic responsibilities are distributed under Dublin among Member States. While rulings like MSS and NS/ME are of course meant to ease pressure on peripheral states, they do so obliquely-that is, without directly elaborating how mutual trust as the basis of solidaristic relations is predicated, not just on fundamental rights protection, but on the system's fair distribution of competencies and capacities, as well. This elision masks the true nature of the underlying deficit of solidarity - and thus hinders introspection into the causes for why differing and inadequate standards of reception and detention continue to exist among European states. More to the point, they disfavor introspection about the role distributive injustice might play in the preservation of such differences. They thus fail to make crucial connections between failures of protection in individual cases with broader structural failure in solidaristic relations between states. Missing, therefore, is a coordination of a specific kind, not the collusion of national state power but a framework for mutual critique-one that is not reducible to the creation of new formal criteria for trusting or suspending trust.

The principle of mutual trust as we find it today continues to risk violating the fundamental rights of individuals - and not just their safety and security before refoulement or ill treatment. It also risks violating the very status of those rights as discrete claims to which one must respond and remain responsive. The system of mutual trust risks projecting, before the fact, certain interpretations of what any claim to protection already means in the context of the Dublin system. Thus a key violation also occurs in the very presumptive framing of the right that is meant to be secured-distributed and parceled as it is among Member States in the difficult ways I have been describing.

This concern reflects something rather poignant about the interconnection between the fates of national democratic states and of those seeking asylum at their shores. Does not an analogous trap, then, confront a Member State within the structure of mutual trust as does the refugee in the procedures of her reception? In other words, a form of conditional trust or conditional "hospitality" that a priori structures the encounter in favour of those with discretion? As Jacques Derrida memorably argued, the stranger "must ask for hospitality in a language which by definition is not his own, the one imposed on him by the master of the house, the host, the king, the lord, the authorities." 102 And here, the choice of the refugee to select the conditions under which she is

\footnotetext{
${ }^{101}$ See Nicolaidis, supra note 52, at 690.

${ }^{102}$ JaCQUes DerRida, OF Hospitality 15 (2000).
} 
to be admitted and to live-as much as the choice of the peripheral state to similarly select on its own the structural context in which Dublin's rules are applied-is constrained. Without presuming to equate the gravity of these constraints, they nevertheless indicate how deeply the task of solidarity runs along both dimensions at once. ${ }^{103}$ In responding to the claims of refugees, Member States and European citizens in this respect fail to see the "refugees" that they, too, are.

If realizing solidarity first entails inquiry into what is owed to one another, it also then entails scrutinizing the grounds upon which the former judgment is to be made. The method of scrutiny offered by the framework of mutual trust - with its enduring emphasis on the formal character of agreement and its derogations - remains inadequate for this kind of second order critique and self-critique. It neglects the background orientations that either inhibit critique or make it possible. These ultimately concern the nature of systemic entanglements in which we always already find ourselves - that is, the ongoing ways states affect one another's capacity to conceptualize and to affirm fundamental rights for those who encounter state power. Solidarity requires precisely this willingness to unsettle the terms upon which we "already are."

\section{E. Solidarity as Fallibilism and Responsiveness: The Structural Possibilities of the Particular Case}

If the demands of legal solidarity cannot be captured adequately by recourse to the formalism of rule-following, what does this mean for the ways post-national solidarity might yet overcome the ideology of sovereignty as the orientation toward "mastery" or "control"? An essential lesson of the above dilemmas of mutual trust seems first to be that post-national solidarity requires a specific sensitivity - one focused on how the nature and structure of coercion are relational, systemic, and changing. In this regard, such sensitivity must track how perceived inadequacies in another's law might always reflect inadequacies in one's own law and how systemic failings structure one's capacities and freedom. Such an orientation is a critical component for solidarity among peoples precisely because sensitivity to such processes complicates and resists the aspiration simply to act either on the formal presumption of agreement or on the basis of one's own prerogative.

On this view, solidarity as a mode of legal integration cannot simply affirm a kind of loyalty codified by respect for the abstract rules of EU law. Instead, post-national solidarity-precisely as this dialectical, systemic critique - requires a certain kind of legal responsibility that reflects (a) terms of mutual dependency and mutual responsibility, and, just as importantly, (b) a dynamic responsiveness to how such responsibility evolves outside of one's control and thus requires critical reinterpretation over time. This second element has been neglected in the cases above. But it is crucial for understanding the constitutional character of solidarity as a structure of political responsibilityresponsibility for the ongoing decisions one is able to take and the grounds on which one takes them.

Violeta Moreno-Lax has recast the principle solidarity in the context of asylum law and Article 80 TFEU in terms of a "double-fairness": fairness at once to the refugee applicant and to fellow Member States. It should "permeate the [Common European Asylum System] on a permanent, ex ante basis and thus guarantee[] cooperation and sharing of burdens in compliance with fundamental rights." 104 This is a persuasive, elegant interpretation of what is immediately, and in the first instance, needed as a matter of positive asylum law. But is it sufficient as an account of solidarity's place in European constitutional theory more broadly?

\footnotetext{
${ }^{103}$ This an insight Advocage General Mengozzi also reflects upon in his recent opinion on the obligation under EU law to issue humanitarian visas to those seeking asylum. See Opinion of Advocate General Mengozzi, Case C-638/16, X and X v. État belge ECLI:EU:C:2017:93 (2017), para. 174 ("In extreme conditions such as those that the applicants have endure . . their option to choose is as limited as the option of the Member States of the Mediterranean Basin to turn themselves into landlocked countries.").

${ }^{104}$ Violeta Moreno-Lax, Solidarity's Reach: Meaning, Dimensions and Implications for E.U. (External) Asylum Policy 24(5) MaAstricht J. Euro. \& COMP. LAW 740, 740-762 (2017).
} 
Moreno-Lax's application of Article 80 to the demands of the CEAS is relatively clear in its normative obligations; it creates a new framework for the equitable sharing of the burdens of asylum processing and for upholding fundamental rights standards. But it remains insufficient in the following respect: the assessment both of what it means to "share" burdens and to uphold fundamental rights is, as we have seen, a deeply contested and evolving affair. It implicates processes of judgment and questions of how one understands and interprets one's normative obligations. The appeal to "fairness" as a moral category cannot presume, on its own, to resolve either underlying conflicts of interpretation or, with Markell, the underlying orientations toward "mastery" and efforts to isolate oneself from vulnerability that endure-even as states might come to agreements that go beyond narrow national self-interest. The structural imbalances, in other words, remain; and solidarity must aspire to more than a new formal rule determining the equitable distribution of asylum seekers. ${ }^{105}$

If solidarity as "double fairness" appears too positivistic to inform European constitutional politics, let me explore a complementary, though distinct formulation. We might instead see solidarity as a principle in the meaning of Herman Heller's "fundamental ethical principles of law," which provide "the doorway through which positively valued social reality daily makes its way into the normativity of the state." 106 Such principles, as David Dyzenhaus has explained, are "suprapositive in the sense of being beyond positive law, [b] ut they are not supracultural - they are principles which formulate the values embedded in our cultural practices which the Rechtsstaat institutionalizes."107

Post-national solidarity would assume a particular meaning, with emphasis on the manner in which a community accepts the heterogeneity and differentiation of its world, how it approaches that world in the spirit of shared commitment. I mean this in two ways. First, solidarity describes cohesion with a view of its conditioning limit and with the consciousness that this limit is itself a contested site of politics. The boundary line is the foundation but also always the contingent result of (unpredictable) political action. ${ }^{108}$ Second, in addition to rejecting any "naturalized" closure of a polity's terms of inclusion and recognition, solidarity recasts the manner in which a polity understands itself to act and, therefore, the image it has of its sovereignty. Sovereignty here refers not merely to the sociological capacity of the state for control—which has indeed diminished under globalization ${ }^{109}$ —nor to ultimate political authority, which, to the contrary, has remained as symbolically powerful as ever, but rather to the project of insulating oneself, asymmetrically and at the expense of others, from the shared vulnerability and plurality ${ }^{110}$ of the world. Solidarity in this light would scrutinize how disagreements among polities concerning their normative obligations might always reflect certain inadequacies in one's own laws and in underlying systemic failings to equitably share not just responsibilities but also one's vulnerabilities.

\section{I. "Positive Possibility" and Different Futures}

A key conceptual move is to see how this more sensitive scrutiny is essentially related to fallibilism in legal judgment-the idea that each particular case might illuminate needed reforms in the existing structure of law. Solidarity, then, emerges through law insofar as legal judgment is able

\footnotetext{
${ }^{105}$ See, e.g. Joined Cases C-643/15 and C-647/15, Slovak Republic and Hungary v. Council, ECLI:EU:C:2017:631, para. 252 (establishing that "the Council, when adopting the contested decision [on refugee relocation from Italy and Greece to other Member States], was in fact required ... to give effect to the principle of solidarity and fair sharing of responsibility ....”).

${ }^{106}$ Hermann Heller, Staalsleltre (Theory of the State) in GESAMMELTE SCHRIFTEN 302, 371 (Tubingen 1992).

${ }^{107}$ David Dyzenhaus, Legality and Legitimacy: Carl Schmitt, Hans Kelsen, And Hermann Heller In Weimar 204 (1997).

${ }^{108}$ See Jacques Derrida, The Other Heading: Reflections on Today's Europe (P. A. Brault \& M. Naas trans., 1992).

${ }^{109}$ See, e.g., SASKia SASSEn, Losing Control: Sovereignty in an Age of Globalization (1996).

${ }^{110}$ See Hannah AREndt, The Human Condition 234, 244 (1958) (calling sovereignty and the desire for it "contradictory to the very condition of plurality" and to the unpredictability to which it gives rise.).
} 
to remain responsive to the particularity of the individual case. In what follows, I attempt to outline preliminary steps to see how fallibilism is what underwrites the integrity of the "double fairness" of one's law at any point in time, as the normative interpretations of what it requires are constantly called to reassessment.

Recall that Habermas based his theory of constitutional patriotism on a dynamic account of constitutionalism, in which norms would be "fallible and revisable." ${ }^{111}$ But just what kind of fallibilism is meant, and does it in truth satisfy the ambitions of post-national solidarity as a constitutional legal principle? Nikolas Kompridis helpfully distinguishes the "fallibilistic consciousness of sciences" from the distinctive fallibilism of "modernity's relation to time."112 The former recognizes that any claim to validity may require revision in the future, depending on the discovery of "new evidence, new arguments, and new experiences." 113 Kompridis argues that such fallibilistic consciousness considers the future to hold a negative possibility, a possibility of "disconfirmation" of a claim to which one confidently subscribes in the present. "If an agent has good reasons to believe $p$, she does not look to the future in hopeful anticipation of reasons to reject $p$, for such an orientation would not be consistent with what it means to have good reasons for believing p." 114 By contrast, modernity's time-consciousness orients itself to the future in a positive manner, "expectant" of a "future different from the past." 115 Only in this case is the future conceived as a "horizon of possibility" that shapes "our responsiveness to present possibility." 16

On this view, a central aspect of the legal process, in which norms are subsequently tested is not to refine their certitude, but to demonstrate how their possibility has not yet been articulated — not just unrealized or imperfectly realized, but in fact not yet recognized for what it might mean. ${ }^{117}$ The case is not an occasion to perfect, but a hope to search for something otherwise. One perceives norms through confrontation with the concrete historical struggles that activate them-and in whose particular exigencies they must be interpreted again.

To think otherwise would subsume application of norms in adjudication to the existing legislative process as it already is, and thereby deprive adjudication of its jurisgenerative, norm-creative potential. Because backwards projection to the "pure norm" threatens a timeless-and thus unchanging-conception of normative meaning, it undermines the creative life of constitutional law and its potential to sustain post-national solidarity. This "defensive" posture of legal solidarity so defined reduces legal process to social maintenance, not transformation.

Early interpretations of the Area of Freedom, Security, and Justice were predicated on precisely this view. Recall that, prior to the intervention of the MSS and NS/ME lines of jurisprudence, early interpretations of mutual trust maintained that national courts should not scrutinize the factual respect for fundamental rights in a given case where enforcement of another Member State's laws is required. Adopting Halberstam's metaphor, this "wholesale" approach took another's laws at their normative face-value as a formal system; mutual trust was a veil that adjudication was not meant to pierce. ${ }^{118}$ As Luisa Marin argues, a "gap in legal accountability" emerged "because a national court should always control, to some extent, the legality of an act of transfer." 119 But not only this. The wholesale approach disappoints, too, because it fails to treat seriously the case

\footnotetext{
${ }^{111}$ HABERMAS, supra note 42 , at 384.

${ }^{112}$ Nikolas Kompridis, Critique and Disclosure: Critical Theory Between Past and Future 180 (2006).

${ }^{113} \mathrm{Id}$.

${ }^{114} I d$.

${ }^{115} \mathrm{Id}$.

${ }^{116} \mathrm{Id}$. at $180-81$.

${ }^{117}$ See, e.g., Jed Rubenfeld, Freedom and Time: A Theory of Constitutional Self-Government 189 (2001).

${ }^{118}$ Daniel Halberstam, "It's the Autonomy, Stupid!" A Modest Defense of Opinion 2/13 on EU Accession to the ECHR, and the Way Forward, 15 GERMAN L. J. 133 (2015).

${ }^{119}$ Luisa Marin, "Only You": The Emergence of a Temperate Mutual Trust in the Area of Freedom, Security and Justice and Its Underpinning in the European Composite Constitutional Order, 2 EUR. PAPERS 141, 149 (2017).
} 
in the fallibilistic register. It fails to see the case as an occasion to test the meaning of norms in search of a positive possibility in both the host and recipient states' laws.

This undermines the moment of encounter and obscures the historical and contingent nature of that prior point of democratic legitimation. New claims, when they arise before us, challenge the determinacy of existing norms. Only once they are acknowledged to do so can they become the subjects of re-cognition, reconstruction, and judgment in a process that would enlarge the space of public reasons under law. ${ }^{120}$ This is the direction in which we must press Habermas's own moving ambition to "realize rights anew in changing circumstances, . . . and to draw out [their] contents more radically." 21

We see this problem more clearly when we understand that, even following MSS and NS/MEas decisive as they were in their changes of EU law's posture toward mutual trust - the "wholesale" metaphor of adjudication continued in large part to control. Remember that the Court in MSS emphasized that Belgium would itself need to "verify how the Greek authorities applied their legislation on asylum" and that the applicant could not be "expected to bear the entire burden of proof." ${ }^{\prime 22}$ But the question remained open as to what proper standard of scrutiny must be applied to the case at hand. The subsequent ruling by the European Court of Justice that Member States must deny the transfer of an asylum seeker where "they cannot be unaware that systemic deficiencies in the asylum procedure" hardly dispelled the wholesale packaging of claims; to the contrary, it confirmed it. ${ }^{123}$ The appeal to systemic deficiencies meant that courts deferred in the individual case not to its particularities but to the generic character of another's legal system. That this judgment was insufficiently robust was subsequently confirmed when states failed to coherently abide by the new terms of formal agreement-and the balance between agreement and forbearance again remained normatively questionable.

\section{Fallibilist Openings}

Here the notion of fallibilism again gains purchase. If the new standard of formal recognition demanded that mutual trust also inquire whether fundamental rights are systematically protected, fallibilism revises the manner in which that scrutiny is conducted and the manner in which the presumption to mutual trust may be overturned. A key question in this regard for courts has been whether to grant individualized review of the case beyond the "wholesale" approach sanctioned by the standard of "systemic deficiencies." Understanding the case in light of fallibilism and responsiveness militates in favor of recentering individual claims in a particular way-understanding the individual case to have bearing not only on the state of fundamental protection abroad, but also on the state of the European Union as a whole and its own normative standards by which such protection can responsibly be judged.

Fallibilism redefines what mutual trust as a process of engagement-that balance between agreement and forbearance-aims to accomplish. To center the case as an occasion to learn means one must sustain a particular dialogue with overarching ambitions and sensitivities. It alters the posture of adjudication to reflect the finitude and partiality of one's existing principles and to tender new interpretations of them in light of a particular case. The rebuttal of mutual trust is viewed not as merely a possibility to disconfirm something "there," but rather an opportunity to inquire more deeply about what might be there. It becomes a powerful and individualized way to press fellow Member States to better respect the rights of asylum seekers, in ways that are not always clear before they have been subject to careful adjudication; and concurrently to realize the need for reliable structures of responsibility-sharing among states in the Dublin system.

\footnotetext{
${ }^{120}$ See Kompridis, supra note 112 , at 136.

${ }^{121}$ HABERMAS, supra note 42 , at 384 .

${ }^{122}$ MSS v. Belgium and Greece, para. 358.

${ }^{123}$ Joined Cases C-411/10 and C-493/10, NS v. Secretary of State for the Home, 2011 ECR I-13905, para. 106.
} 
This fallibilist approach entails the shift, then, from a "wholesale" to a "retail" method of inquiry. And we see, in fact, the European judiciary responding to such need in its most recent case law in the field of asylum. In Tarakhel v. Switzerland, the European Court of Human Rights departed from its MSS "systemic deficiencies" standard and required that Swiss authorities obtain "individual guarantees ... that the applicants would be taken charge of in a manner adapted to the age of the children and that the family would be kept together." ${ }^{\prime 24}$ The decision was guided in part by sensitivity to the specific vulnerabilities of the applicants, understood in light of the kind of treatment they might likely face if not afforded a stricter non-refoulement review of their pending transfer. The Court there responded to two dimensions of rights protection: (1) the particular position of the individuals involved and their vulnerability; and (2) the particular "patchwork" of rules that asylum seekers factually encounter in the European legal space-in this instance prompted by Switzerland's status as a non-EU Member State. ${ }^{125}$

The CJEU soon followed suit in the case CK and Others $v$. Slovenia, which mandated that Slovenian authorities assess the risk to which a woman affected by mental disease would likely be exposed both during and after her prospective transfer to Croatia, despite no apparent structural inadequacy of the latter's asylum system. ${ }^{126}$ The judgment in $C K$ is especially notable for the direction in which its interpretation of legal principle runs. The Court places added responsibility to the discretionary "sovereignty" clause Dublin III's Article 17, paragraph 1 by offering an expansive reading of the prior NS/ME criteria found in Article 3, paragraph 2. And it does so in light of the challenges asylum seekers face in the particular case at hand. It affirms that responsibilities attending a state's discretionary judgment must thereby remain open. States must be responsive to assessing the factual potential for concrete applicants to secure realization of their fundamental rights, the meaning of which will depend upon their particularized level of needed care.

This individualized review thereby reflects the positive inflection of fallibilism as an understanding of what it means to adjudicate the meaning and scope of rights as such. The context of the particular case does not merely tender the semantic material from which normative claims are made. Rather, it is constitutive of this normativity, for only by inquiring into the claims to particular harm can we understand the normative meaning of rights with new determinacy. Otherwise, they would express norms too abstract to teach us much about what to do politically. The right that is to be protected "lives" only in a sequence of such determinations.

This form of judicial review asks the Court to peer more deeply into the particularities of how fellow jurisdictions implement principles and policy-as individuals engage in the concrete demands placed upon them by interwoven European asylum procedures. European asylum law here becomes much more than a set of normative expectations or, even, procedures with "systemic" characteristics. Looking past the normative or systemic character of law requires one to understand the background conditions - whether hermeneutic understandings of principles or distributions of practical capacity - for the realization of rights in practice. And through this process one can come to understand both the normative soundness and factual adequacy of the legal standards contained in mutual recognition instruments.

\section{Dialogic and Democratic Constitutionalism Beyond the Nation-State}

Such dynamic formulations of what rights protection demands can then also inspire the dynamic justificatory discourses in the broader public sphere. Rulings of the Court are the starting point, not the conclusion, of renewed political deliberation over the correct balance under mutual trust,

\footnotetext{
${ }^{124}$ Tarakhel v. Switzerland, App. No. 29217/12, (2014), para. 122.

${ }^{125}$ See Evelien Brouwer, Mutual Trust and Human Rights in the AFSJ: In Search of Guidelines for National Courts, 1 EuR. PAPERS 893, 919 (2016).

${ }^{126}$ ECJ, Case C-578/16 PPU, CK, HF, and AS v. Republic of Slovenia, ECLI:EU:C:2017:127 (Feb. 16, 2017), https://curia. europa.eu/juris/liste.jsf?language $=$ en $\&$ td $=$ ALL\&num $=$ C-578/16\%20PPU.
} 
given the evolution of one's understanding of the meaning and implementation of rights. Fallibilism reflects a certain mode of "governance" 127 under mutual trust, in which courts scrutinize the myriad ways rights might fail to protect (politically under-represented) individuals or groups in particular cases - and then uses this as a basis for renewed democratic contestation over the proper bounds of policy and principle. Here, public debate evaluates national standards, but also conducts comparative inquiry into fellow Member States' and European law. The process begins not from first principles but from the particular constellations of fact and failures to protect that require one to reassess what fundamental guarantees require. This is, in the end, why both legitimacy and solidarity are so deeply interwoven with fallibilistic responsiveness.

In such a view, courts would work to disclose new possibilities through their encounters with the case that in turn would prompt—and require-a new legislative process of ethical transformation. This inter-connection between adjudication and legislation is essential to the "learning process" of the democratic constitutional state. The case expected as a site of (positive) possibility might always disclose to us something new about the state of our world and, in turn, something in our existing norms we previously failed to see or understand. Perhaps it will illuminate those ways we fail to be sufficiently attentive to one another's needs and interests, indeed, attentive to what our own personal needs and interests might in fact be, or become. Because a confrontation would thereby require something of us as citizens, the case in constitutional adjudication would also have bearing on the need for renewed discourses of justification. Constitutional adjudication would thereby represent a commitment to see the law grow democratically in the wake of the court's judgment.

Depending on how one perceives the burdens of this assessment, the fallibilistic presumption of mutual trust implicitly and potentially might always in fact give way. The principle of mutual trust, properly read in its capacity to generate solidarity through law, requires this possibility. Abiding by a principle of solidarity, the transfer state would in fact bear a burden to assess and, further, to aim to remedy the deficiencies in asylum procedures among recipient states. But this assessment cannot be understood as merely a license for withdrawal and the discretionary act of national sovereignty, as before. In its responsiveness to fact, it cannot aim to react and compensate for prior deficiencies of a framework it intends simply to refine.

Solidarity's dialogue is more demanding than better inclusion into the existing set of affairs, in which national prerogatives are relatively fixed and stable. In triggering sovereign discretion, postnational solidarity also changes the expectations of who and what is sovereign in light of the interconnected causes of failure in the particular case. Sovereignty is invoked here not in the interest of defending national prerogatives in isolation, but to engage in an ongoing dialogic assessment of the meaning of fundamental rights that activate the need for this discretion. This kind of responsiveness cannot be reduced to formal criteria because it responds to conditions that are always changing - just as the realization of rights always demands we attend to new meanings of those rights and new constellations of facts that impede their realization. These are conditions over which we cannot presume to exercise control. And in this space, the renewed dynamic balance of agreement and forbearance in mutual trust again finds its place.

Assessing the fairness of such balance - whether it abides by the fair sharing of responsibilities among states or does enough to protect rights of asylum seekers-is predicated upon responsiveness to an unpredictable evolution of factual situations. These not only continually unsettle our confidence that fairness has been achieved but, more deeply and importantly, also our understanding of what fairness as a principle means and might yet mean. For this reason, in the context of ongoing reforms to the Dublin system, the appeal by Visegrad states for a highly discretionary mechanism of "flexible, effective solidarity" is manifestly inadequate. ${ }^{128}$ But unsatisfactory, too, are frameworks for emergency relocation measures, increased European financial contributions,

\footnotetext{
${ }^{127}$ See generally Maduro, supra note 51, at 815 .

${ }^{128}$ See Council of the European Union, Solidarity and Responsibility in the Common European Aslyum System, Progress Report by Slovak Presidency, Council Doc. 15253/16.
} 
and European Asylum Support Office assistance. ${ }^{129}$ Both cases take far too much for granted the underlying distributions of state responsibility and think hardly at all about the need for new structural arrangements prompted by new interpretations of rights-interpretations that would reach to the heart of the EU's carrier sanctions regime and requirements of its humanitarian visa obligations, to take two examples. ${ }^{130}$ A solidaristic approach cannot reduce merely to improving the "effectiveness" of existing schemes of protection; it must also reflect a deliberative structure that questions precisely the background presumptions about what "effective protection" means as a legal and practical matter in the world.

\section{Setting One's Law Adrift: Further Contexts}

Such an approach, of course, is not limited to the context of asylum. And, indeed, the CJEU has applied the individualized nature of judicial review also to mutual trust cooperation in criminal matters under the AFSJ. In Aranyosi, the adequacy of prison conditions in Hungary and Romania prompted concern for violations of the prohibition of torture and other inhuman, degrading treatment, and the Court on that basis accepted exceptional limitations to the lawfulness of European Arrest Warrant extraditions. ${ }^{131}$ The Court there developed a two-prong test to ascertain whether fundamental rights are compromised: first, an assessment of the general operational adequacy of the justice system in the issuing state and the "real risk" of a breach of fundamental rights; and second, a specific, individualized assessment of that risk to the individual in the case at hand. ${ }^{132}$

Recently, prompted by the ongoing rule of law crises in Hungary, Poland, and other EU Member States, the "real risk" test has been applied to scrutinize conditions in which the independence of the judiciary and thus the right to a fair trial might be compromised. In its Celmer ruling, the CJEU accepted Aranyosi's two-prong test in the assessment of "real risks" to the right to a fair trial. ${ }^{133}$ Some commentators lamented that the second prong's individualization requirement, when applied to evaluations of judicial independence and prospective judicial procedures, is a "Herculean hurdle" so daunting to satisfy that it seems simply to render the test impotent. ${ }^{134}$ Alternatively, others decried Celmer for risking "legal chaos," as some courts now would "regularly refus[e] to recognize judgments from courts in Poland" while others would continue to trust them. ${ }^{135}$

Nevertheless, these judgments have had remarkable jurisgenerative properties. And these are salient to how we might understand the productive creation of solidarity through law as an exercise of responsiveness. Consider in this regard the recent decision by the Karlsruhe Higher Regional Court concerning the extradition from Germany of a Latvian citizen to Poland. ${ }^{136}$ Faced with Celmer's daunting second prong, ${ }^{137}$ the German court submitted to its Polish

\footnotetext{
${ }^{129}$ See Evangelia Tsourdi, Solidarity at Work? The Prevalence of Emergency-Driven Solidarity in the Administrative Governance of the Common European Asylum System, 24 MAASTRICHT J. EUR. \& COMP. L. 667 (2017).

${ }^{130}$ To consider the evaluation of Advocate General Mengozzi concerning the provision of humanitarian visas, see, ECJ, Case C-638/16 PPU, X and X v État Belge, ECLI:EU:C:2017:93 (Mar. 7 2017), para. 174, https://curia.europa.eu/juris/liste.jsf? language $=$ en\&td $=$ ALL\&num $=\mathrm{C}-638 / 16 \% 20 \mathrm{PPU}$.

${ }^{131}$ EJC, Joined Cases C-404/15 and C-659/15 PPU, Pál Aranyosi and Robert Căldăraru v. Generalstaatsanwaltschaft Bremen, ECLI:EU:C:2016:198 (Apr. 5 2016).

${ }^{132} I d$. at paras. $88-94$.

${ }^{133}$ ECJ, Case C-216/18 PPU, Minister for Justice and Equality v. LM, 2018 ECLI:EU:C:2018:586, (Jul. 25, 2018) paras. 61-68, https://curia.europa.eu/juris/liste.jsf?language=en\&td=ALL\&num=C-216/18\%20PPU.

${ }^{134}$ See Wouter van Ballegooij \& Petra Bárd, The CJEU in the Celmer Case: One Step Forward, Two Steps Back for Upholding the Rule of Law within the EU, VERFASSUNGSBLOG (July 29, 2018), https://verfassungsblog.de/the-cjeu-in-the-celmer-caseone-step-forward-two-steps-back-for-upholding-the-rule-of-law-within-the-eu.

${ }^{135}$ See R. Daniel Kelemen, Is Differentiation Possible in Rule of Law?, CoMP. Eur. PoL. (forthcoming).

${ }^{136}$ Karlsruhe Higher Regional Court, 1st Criminal Tribunal, 7 Jan. 2019, Ausl 301 AR 95/18.

${ }^{137} \mathrm{Id}$. at paras. 18-19 (disposing of the first prong in acknowledging the forced retirement of higher court judges and the two ongoing infringement procedures launched against Poland by the European Commission).
} 
colleagues a list of twelve questions that probed the procedures and guarantees for judicial independence. ${ }^{138}$ These questions inquired into the nature of the appellate process and the composition of the competent courts, including the background of the Polish judges who were to be involved. The German court further pressed their Polish counterparts on the vulnerability of the proceedings to the vague, politically tendentious "extraordinary appeal" procedure to the Polish Supreme Court. Perhaps most notably, the Karlsruhe Court asked for assurances that the Polish government would not initiate disciplinary proceedings against the judges hearing the present case. The German court accepted the Polish responses to be "reliable and credible enough" to approve the extradition, but included a number of conditions, including the participation of the German embassy in the trial with access to the accused while in custody. ${ }^{139}$

The exchange between the courts-one envisioned by the CJEU in its Aranyosi framework requiring requests for supplementary information and "dialogue"140_-is a poignant, if rare example of the critical potential of legal procedures to create the kinds of exchanges in law that might yet create solidaristic ties. The German court's approach is noteworthy for its imaginative adjudication: the way it harnesses the involvement of other state authorities-both German and Polish; the deliberative structure of its examination; and its commitment to provide oversight of the proceedings into the future.

In the context of the broader rule of law crisis, this kind of approach seems novel and salutary. It shifts the terms of confrontation to a creative plane - and builds solidarity alongside more punitive, disciplinary measures easily cast as confrontations among Member States or between Poland and the European Commission. While these latter kinds of confrontations leave European politics vulnerable to the old sovereigntist divisions, the work of the German court breaks free of this logic. It presents neither withdrawal from cooperation, nor the insistence of national prerogative-nor does it hide behind the formalities of new rules of recognition or seek merely corrective measures.

Instead, the work here is forward-looking and remains responsive to the evolving facts of the case, including the prospective response of Polish institutions - both an aggressive executive, but also an embattled and possibly cooperative Polish judiciary. In carefully reasoning through what might yet happen, the German court is able to disaggregate Polish state power and to scrutinize the Polish executive's potential intrusion into the legal process while instructing German authorities to concretely support the procedures of Polish courts. This ongoing responsiveness results in a willingness to press the boundaries of state responsibility and to creatively imagine how ongoing dialogue unpredictably shapes the meaning of legal obligation.

One can imagine a similar process triggered from one Member State to another in light of failures in asylum reception and processing, precisely to understand more carefully when the invocation of the sovereignty clause is in fact mandated and recognition cannot be granted. This time, the act would not be unilateral de-recognition, resulting in no transfer, but also inquiry into the nature and cause of the failure to protect rights. In this light, the requirement under EU law to invoke the sovereign discretion clause would be based not only on the attribution of failure but also on willingness to understand how that failure is already a failure of collective responsibility with causes that implicate, too, the broader structural features of the European system - to which the transferring state has consented and for which it bears its share of liability. Here, fault would be attributed to the receiving state but to the involvement, or lack thereof, of fellow Member States, as well.

A process like this gets us a good deal closer to understanding how solidarity can be a product of law and of legal relationships in a deeply plural European society. In the course of this dialogue, legality secures not merely rule-following but a discursive practice of solidarity-in Max

\footnotetext{
${ }^{138} I d$. at paras. $22-35$.

${ }^{139}$ Maximilian Steinbeis, Editorial: Brother's Keeper, VERFASSUnGSBLOG (Feb. 9, 2019), https://verfassungsblog.de/brotherskeeper/.

${ }^{140}$ Joined Cases C-404/15 and C-659/15 PPU, Aranyosi and Căldăraru, ECLI:EU:C:2016:198 (Apr. 5 2016), paras. 76-77.
} 
Steinbeis's lovely phrase, "a practice of transnational judicial taking care of each other."141 Taking care of one another means inviting mutual surprise and mutual learning-and thus to care for the conditions of this learning. To accept that one's involvement with another might prompt unexpected obligations, obligations which might set one, equally unexpectedly, adrift from the settled presumptions and insular orientations of one's own law. Insofar as one is beholden to others as they are similarly beholden in return, one becomes aware of the "refugee" one is. And if solidarity is the product of law understood to be inflected by the positive possibility of creative renewal, then solidarity does not integrate what is already recognized. It becomes creative, transformative-modulating what is into what might yet be. The refugee, of course, by virtue of her displacement and exclusion, cannot hope merely to sustain what already is; she must hope to find political community anew.

\footnotetext{
${ }^{141}$ Steinbeis, supra note 139.
} 